October 2000 - NREL/TP-580-28893

\title{
Determining the Cost of Producing Ethanol from Corn Starch and Lignocellulosic Feedstocks
}

\author{
A Joint Study Sponsored by: \\ U.S. Department of Agriculture and \\ U.S. Department of Energy
}

Andrew McAloon, Frank Taylor, and Winnie Yee U.S. Department of Agriculture Eastern Regional Research Center Agricultural Research Service

Kelly Ibsen and Robert Wooley National Renewable Energy Laboratory Biotechnology Center for Fuels and Chemicals

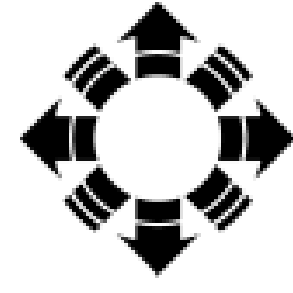

NPEI

National Renewable Energy Laboratory

1617 Cole Boulevard

Golden, Colorado 80401-3393

NREL is a U.S. Department of Energy Laboratory

Operated by Midwest Research Institute $\bullet$ Battelle $\bullet$ Bechtel

Contract No. DE-AC36-99-G010337 


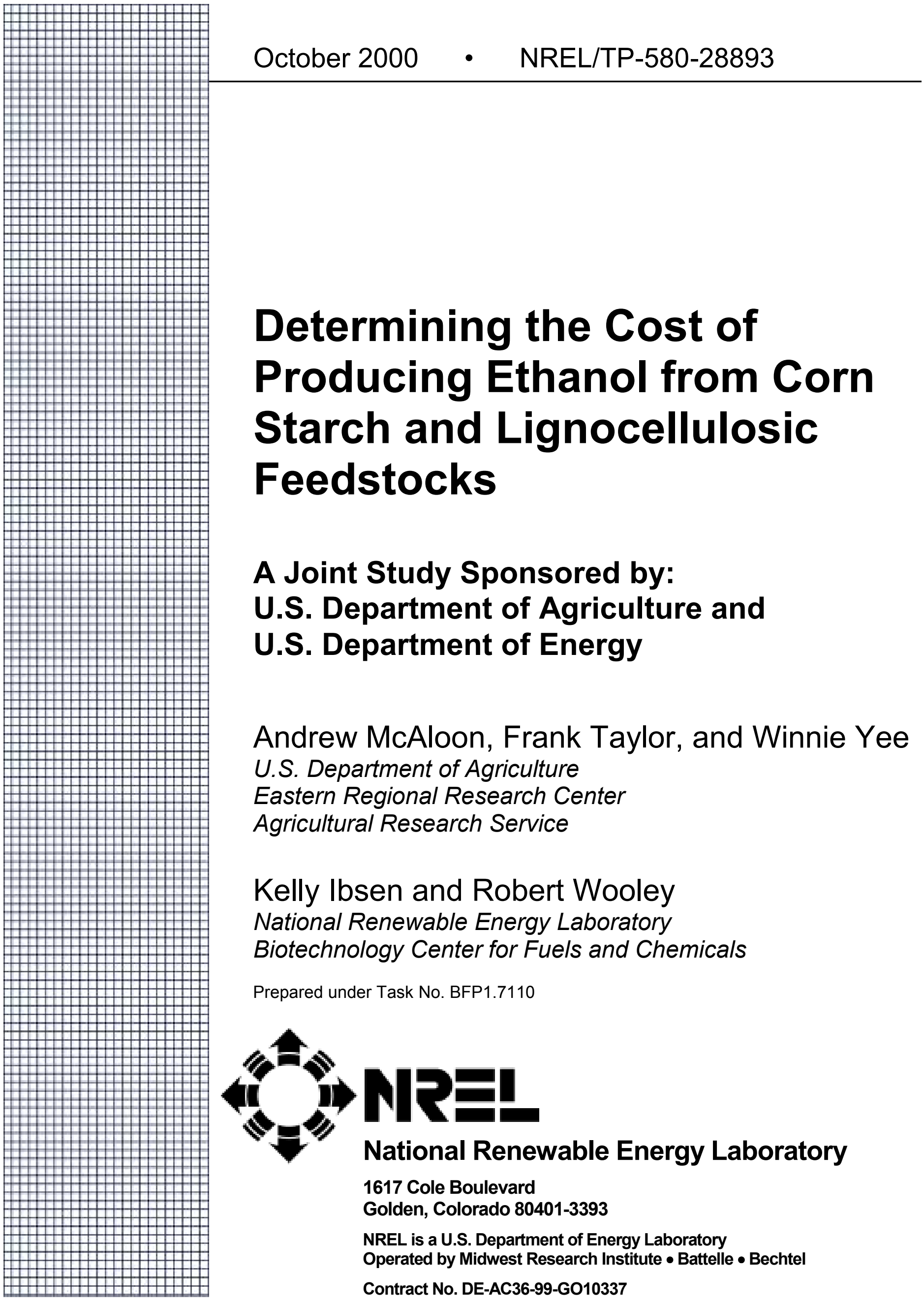




\section{NOTICE}

This report was prepared as an account of work sponsored by an agency of the United States government. Neither the United States government nor any agency thereof, nor any of their employees, makes any warranty, express or implied, or assumes any legal liability or responsibility for the accuracy, completeness, or usefulness of any information, apparatus, product, or process disclosed, or represents that its use would not infringe privately owned rights. Reference herein to any specific commercial product, process, or service by trade name, trademark, manufacturer, or otherwise does not necessarily constitute or imply its endorsement, recommendation, or favoring by the United States government or any agency thereof. The views and opinions of authors expressed herein do not necessarily state or reflect those of the United States government or any agency thereof.

Available electronically at http://www.doe.gov/bridge

Available for a processing fee to U.S. Department of Energy and its contractors, in paper, from:

U.S. Department of Energy

Office of Scientific and Technical Information

P.O. Box 62

Oak Ridge, TN 37831-0062

phone: 865.576 .8401

fax: 865.576.5728

email: reports@adonis.osti.gov

Available for sale to the public, in paper, from:

U.S. Department of Commerce

National Technical Information Service

5285 Port Royal Road

Springfield, VA 22161

phone: 800.553.6847

fax: 703.605.6900

email: orders@ntis.fedworld.gov

online ordering: http://www.ntis.gov/ordering.htm

Printed on paper containing at least $50 \%$ wastepaper, including $20 \%$ postconsumer waste 


\section{Summary}

The mature corn-to-ethanol industry has many similarities to the emerging lignocelluloseto-ethanol industry. It is certainly possible that some of the early practitioners of this new technology will be the current corn ethanol producers. In order to begin to explore synergies between the two industries, a joint project between two agencies responsible for aiding these technologies in the Federal government was established. This joint project of the U.S. Department of Agriculture's Agricultural Research Service (USDAARS) and the U.S. Department of Energy (DOE) with the National Renewable Energy Laboratory (NREL) looked at the two processes on a similar process design and engineering basis, and will eventually explore ways to combine them. This report describes the comparison of the processes, each producing 25 million annual gallons of fuel ethanol. This paper attempts to compare the two processes as mature technologies, which requires assuming that the technology improvements needed to make the lignocellulosic process commercializable are achieved, and enough plants have been built to make the design well-understood. Assumptions about yield are based on the assumed successful demonstration of the integration of technologies we feel exist for the lignocellulose process. In order to compare the lignocellulose-to-ethanol process costs with the commercial corn-to-ethanol costs, it was assumed that the lignocellulose plant was an $\mathrm{N}^{\text {th }}$ generation plant, assuming no first-of-a-kind costs. This places the lignocellulose plant costs on a similar level with the current, established corn ethanol industry, whose costs are well known. The resulting costs of producing 25 million annual gallons of fuel ethanol from each process were determined. The figure below shows the production cost breakdown for each process. The largest cost contributor in the corn starch process is the feedstock; for the lignocellulosic process it is the depreciation of capital cost, which is represented by depreciation cost on an annual basis.

Comparative Production Costs for Starch and Lignocellulose Processes (1999\$)

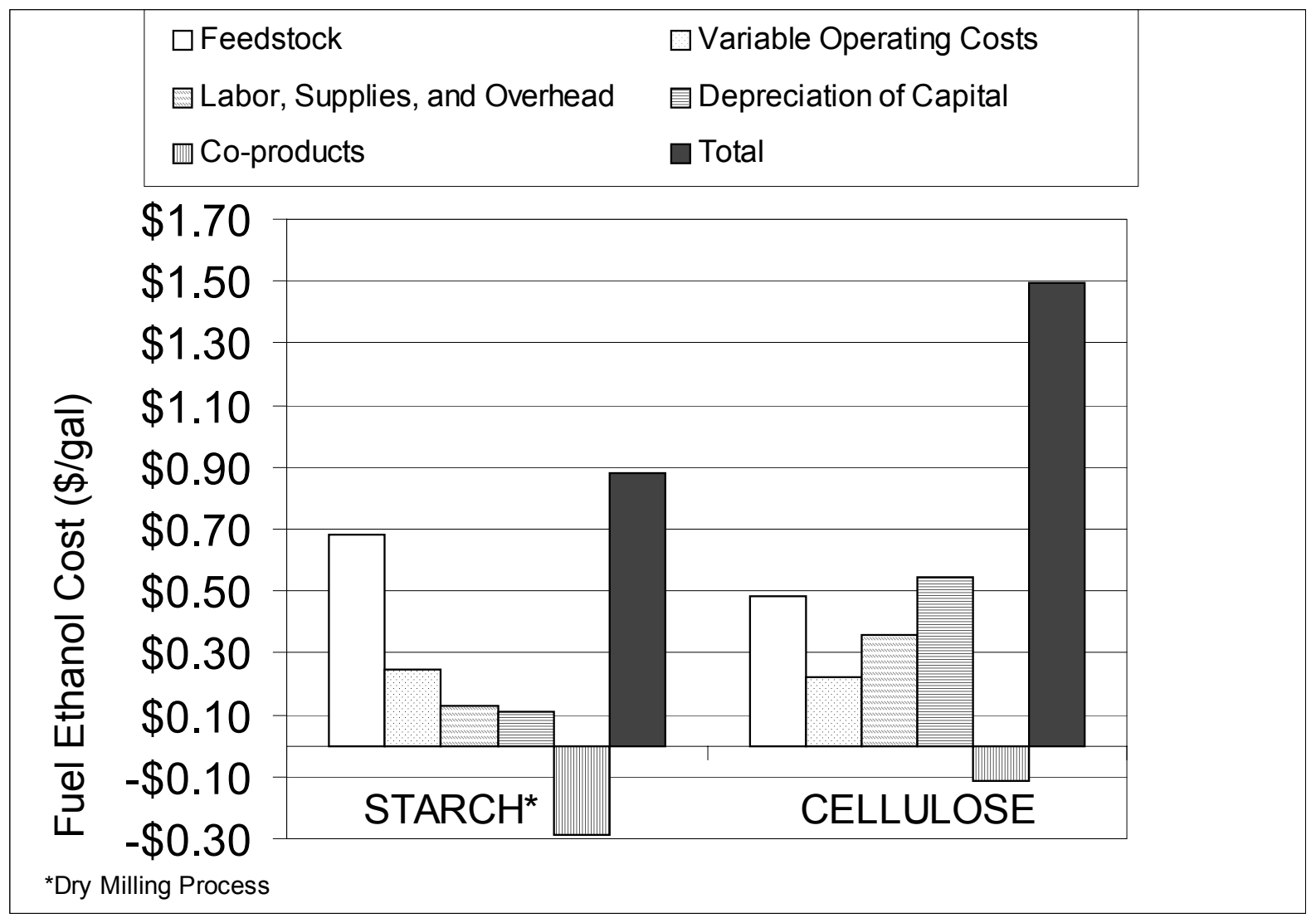


Table of Contents

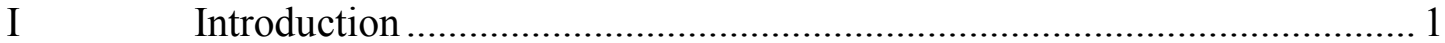

II Comparing the Corn Industry and a Lignocellulose-Based Industry.......... 3

II.1 History of the Corn Ethanol Industry ...................................................... 3

II.2 Status of Lignocellulose-to-Ethanol Process.......................................... 4

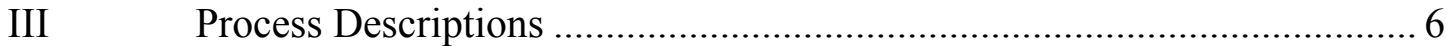

III.1 Corn Starch Feedstock-to-Ethanol Process Description ........................... 6

III.2 Lignocellulose Feedstock-to-Ethanol Process Description........................ 8

III.3 Primary Process Differences ........................................................... 9

IV Normalization of Design and Economic Models .................................. 10

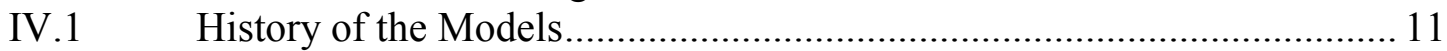

IV.2 Methodology for Achieving the Same Basis.......................................... 12

$\mathrm{V} \quad$ Changes Required in the Process Models .............................................. 15

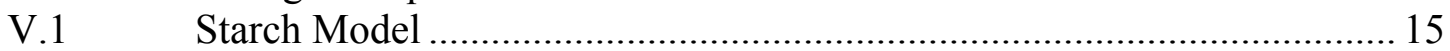

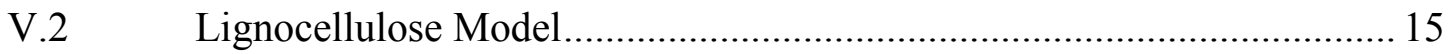

VI Production Costs of Fuel Ethanol.......................................................... 17

VI.1 Production Costs for the Starch Process ................................................. 18

VI.2 Production Costs for the Lignocellulose Process ..................................... 20

VI.3 Comparison of Costs .................................................................... 23

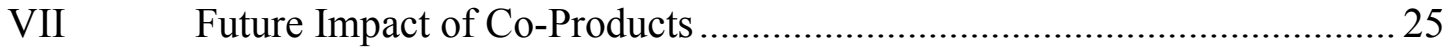

VII.1 The Future of Starch Process Co-Products ..............................................2 26

VII.2 The Future of Lignocellulose Process Co-Products .................................. 26

VIII Prospects and Challenges for a Combined Process................................. 27

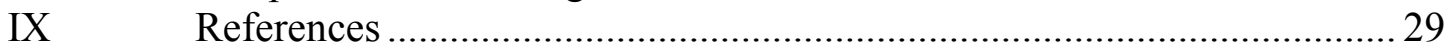

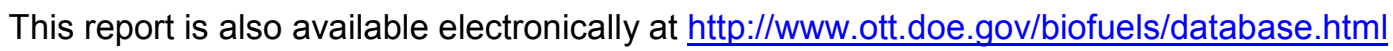




\section{List of Tables}

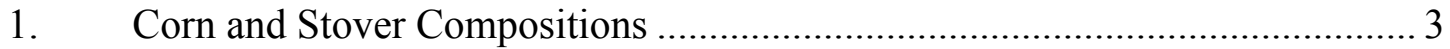

2. DDG and Lignocellulosic Residue Composition and Production................... 10

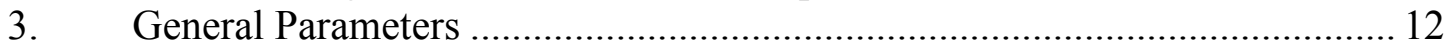

4. Production Costs for the Starch Process ...................................................... 18

5. Capital Costs by Process Area (1999\$) ........................................................ 19

6. Production Costs for the Lignocellulose Process (1999\$) ............................. 20

7. Capital Costs by Process Area (1999\$) ....................................................... 22

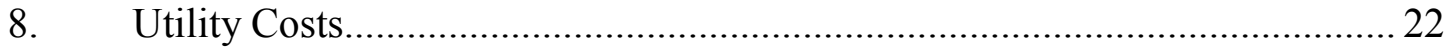




\section{List of Figures}

1. Corn Starch-to-ethanol Process Flow ............................................................ 6

2. Lignocellulose-to-ethanol Process Flow ...................................................... 8

3. Comparison of Starch and Lignocellulose Process Stainless Steel Tank Cost 13

4. Comparison of Starch and Lignocellulose Process Heat Exchanger Cost ...... 14

5. Production Costs in Dollars per Gallon of Fuel Ethanol (1999\$) ................... 17

6. Effect of Changing Feedstock Cost on Fuel Ethanol Production Cost ........... 23

7. Starch Costs by Process Area (1999\$) ....................................................... 24

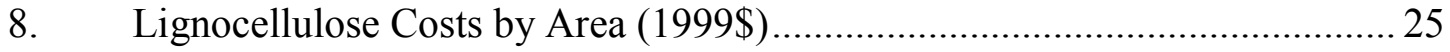




\section{List of Acronyms}

$\begin{array}{ll}\text { ARS } & \begin{array}{l}\text { Agricultural Research Service } \\ \mathrm{CO}_{2}\end{array} \\ \text { carbon dioxide } \\ \text { chemical oxygen demand } \\ \text { CSREES } & \text { Cooperative State Research, Education, and Extension Services } \\ \text { DCFROR } & \begin{array}{l}\text { Discounted Cash Flow Rate of Return } \\ \text { DDG }\end{array} \\ \text { Distillers' Dried Grains } \\ \text { DOE } & \text { U.S. Department of Energy } \\ \text { ERS } & \text { Economic Research Services } \\ \text { FBC } & \text { Fluidized Bed Combustor } \\ \text { GMO } & \text { genetically modified organism } \\ \text { GRAS } & \text { generally regarded as safe } \\ \text { GUI } & \text { Graphical User Interface } \\ \text { kW } & \text { kilowatt } \\ \text { kWh } & \text { kilowatt-hour } \\ \text { NREL } & \text { National Renewable Energy Laboratory } \\ \text { OEPNU } & \text { Office of Energy Policy and New Uses } \\ \text { ORNL } & \text { Oak Ridge National Laboratory } \\ \text { USDA } & \text { U.S. Department of Agriculture }\end{array}$




\section{Introduction}

The U.S. Department of Energy (DOE) is promoting the development of ethanol from lignocellulosic feedstocks as an alternative to conventional petroleum transportation fuels. Programs sponsored by DOE range from research to develop better cellulose hydrolysis enzymes and ethanol-fermenting organisms, to engineering studies of potential processes, to co-funding initial ethanol from lignocellulosic biomass demonstration and production facilities. This research is conducted by various national laboratories, including the National Renewable Energy Laboratory (NREL) and Oak Ridge National Laboratory (ORNL), as well as by universities and private industry. Engineering and construction companies and operating companies are generally conducting the engineering work.

The U.S. Department of Agriculture (USDA) has an active program devoted to the corn ethanol industry. This program includes economic and policy studies by the Office of Energy Policy and New Uses (OEPNU) and the Economic Research Services (ERS), scientific research programs by the Agricultural Research Service (ARS) and the Cooperative State Research, Education and Extension Services (CSREES). Areas of scientific research address the establishment of new higher-value ethanol co-products, the development of microbes capable of converting various biomass materials into ethanol, improved processes for the enzymatic saccharification of corn fibers into sugars, and various methods of improving corn ethanol process efficiencies.

The mature corn-to-ethanol industry has many similarities to the emerging lignocelluloseto-ethanol industry. It is certainly possible that some of the early practitioners of this new technology will be the current corn ethanol producers. ${ }^{1,2,3}$ In order to begin to explore synergies between the two industries, a joint project between two agencies responsible for aiding these technologies in the Federal government was established. This joint project of the USDA-ARS and DOE with NREL looked at the two processes on a similar process design and engineering basis, and will eventually explore ways to combine them. This report describes the comparison of the processes, each producing 25 million annual gallons of fuel ethanol. This paper attempts to compare the two processes as mature technologies, which requires assuming that the technology improvements needed to make the lignocellulosic process commercializable are achieved, and enough plants have been built to make the design well-understood. Assumptions about yield are based on the assumed successful demonstration of the integration of technologies we feel exist for the lignocellulose process. In order to compare the lignocellulose-to-ethanol process costs with the commercial corn-to-ethanol costs, it was assumed that the lignocellulose plant was an $\mathrm{N}^{\text {th }}$ generation plant, assuming no first-of-a-kind costs. This places the lignocellulose plant costs on a similar level with the current, established corn ethanol industry, whose costs are well known.

The feedstock used for each process is different but related. There were 9.76 billion bushels of corn, a commodity crop, produced in the 1998-1999 crop year. Of this, 526 million bushels (14.7 million tons at $15 \%$ moisture) were used in the corn ethanol 
industry to produce fuel ethanol. ${ }^{4}$ Corn stover, the residue left in the fields after harvesting corn, has been identified as a near- to mid-term agriculture residue feedstock for the lignocellulose-to-ethanol process. Corn stover has a high carbohydrate content, can be collected in a sustainable fashion, and will provide economic benefits to the farm community.

Corn kernels have starch, which is an alpha-linked glucose polymer that can be easily broken down to glucose monomers and fermented to ethanol. It has fiber, which encases the starch, and about $15 \%$ moisture. An approximate composition of corn is shown in Table 1. In this analysis of the dry mill corn-to-ethanol process, a slightly different and simpler composition for corn (on a dry weight basis, $70 \%$ starch, and for nonfermentables, $18 \%$ suspended and $12 \%$ dissolved) was used. The market price of corn varies, ranging from $\$ 1.94$ to $\$ 3.24$ per bushel during the last 3 years. ${ }^{5}$ For this analysis, $\$ 1.94$ per bushel was used. Currently, the maximum amount of pure ethanol that can be made from a bushel of corn is 2.74 gallons (98 gallons per ton at $15 \%$ moisture or 115 gallons per dry ton) before denaturation. This is less than the stoichiometric yield of ethanol from starch because the fermentation process necessarily yields yeast cells and byproducts in addition to carbon dioxide and ethanol. Yield is primarily dependent on the starch content, which may vary considerably. For this analysis, a yield of 114 gallons per dry ton (2.71 gallons per bushel) was used.

Corn stover contains considerable quantities of cellulose, a beta-linked glucose polymer, which is more difficult to break down to glucose monomers than the alpha-linked polymer in starch. In addition, it contains hemicellulose, which is a more complex polymer of several sugars. The predominant sugars in hemicellulose are xylose and arabinose. These five-carbon sugars can also be fermented to ethanol with the proper microorganism. The maximum theoretical yield from corn stover with the composition listed in Table 1 is 107 gallons per dry ton (or 91 gallons per ton at $15 \%$ moisture). For this analysis, a yield of 69 gallons of pure ethanol per dry ton was used, which equates to an average yield of $65 \%$ of the cellulose and hemicelluosic polymers. Entwined around the two sugar polymers is lignin, a polymer that does not contain sugars. Lignin, like the fiber in corn, has a by-product value. The fiber by-product is sold as Distillers' Dried Grains with solubles, or DDG. Lignin, currently recognized for its fuel value, may have a better co-product value, as yet unrealized. Stover is typically $15 \%$ moisture, although it can vary depending on age, growing conditions, and variety. Because the collection of stover is a new industry, there is little data on the collection costs. The results of a small stover collection program in 1997-1998 by Iron Horse Custom Farming of Harlan, Iowa, reported stover collection costs between $\$ 31-\$ 36$ per dry ton. ${ }^{6}$ Studies by contractors for DOE have reported a range of $\$ 35-\$ 46$ per dry ton. ${ }^{1,2,3}$ Because the stover is considered a residue, it is expected that its price might not fluctuate as much as a commodity crop like corn. However, demand for stover from an established lignocellulosic ethanol industry could escalate the price. For this analysis, $\$ 35$ per dry ton was used. 
Table 1. Corn and Stover Compositions

\begin{tabular}{|l|r|l|r|}
\hline \multicolumn{1}{|c|}{ Corn $^{7}$} & \% Dry Basis & \multicolumn{1}{c|}{ Corn stover $^{8}$} & \% Dry Basis \\
\hline \hline Starch & 72.0 & Cellulose & 37.3 \\
\hline Hemicellulose/Cellulose & 10.5 & Galactan/Mannan & 1.4 \\
\hline Protein & 9.5 & Xylan & 20.6 \\
\hline Oil & 4.5 & Arabinan & 2.1 \\
\hline Sugars & 2.0 & Lignin & 17.5 \\
\hline Ash & 1.5 & Ash & 6.1 \\
\hline Total & 100.0 & Acetate & 2.0 \\
\hline & & Extractives & 13.0 \\
\hline & & Total & 100.0 \\
\hline \% Moisture & 15.0 & \% Moisture & 15.0 \\
\hline
\end{tabular}

It is known that 1 acre yields about 130 bushels ( 3.65 tons at $15 \%$ moisture) of corn, ${ }^{5}$ and about 1 ton of harvested corn yields 1 dry ton of stover. About $30 \%$ of the stover is currently thought to be available for collection. The remaining stover needs to be left on the field for erosion control. With an estimated 240 million dry tons of stover produced, the 80 million dry tons available for harvesting is equivalent to 6 billion gallons of ethanol. ${ }^{6}$

\section{Comparing the Corn Ethanol Industry and a Lignocellulose-Based Industry}

While the corn ethanol industry is new compared to petroleum refining or chemical process industries, it has a history that can be used to develop process designs and cost estimates with reasonable accuracy. In contrast, the conceptual lignocellulose process design is based on research data. Hence, a higher degree of uncertainty is associated with the design for the latter process.

\section{II.1 History of the Corn Ethanol Industry}

In 1999, approximately 1.48 billion gallons (112 trillion Btu) of fuel ethanol was blended with gasoline for use in motor vehicles. ${ }^{9}$ Most ethanol in the United States is produced by either a wet milling or dry milling process and utilizes shelled corn as the principal feedstock. Facilities using the wet milling process have greater production capacities, are more capital intensive and produce a greater variety of products than dry milling facilities. The wet milling process converts corn into corn oil, two animal feed products (corn gluten feed and corn gluten meal), and starch-based products such as ethanol, corn syrups, or cornstarch. Approximately $60 \%$ of the ethanol produced is from wet mills. ${ }^{10}$ Farmer's organizations building mills today favor the dry mill since it requires less capital to build, a smaller staff to run, and tends to receive tax advantages due to smaller capacity. The dry milling process traditionally generates two products only - ethanol and DDG, an animal feed product. Both processes also generate carbon dioxide $\left(\mathrm{CO}_{2}\right)$ which is captured and marketed in some plants.

The ethanol industry's history goes back to the oil embargo in the 1970s and the concern at that time about a lack of reliable energy sources. Since then, the technology used in the ethanol dry milling process has evolved and the newer plants generally are more efficient 
processing facilities. As a result, the costs to produce ethanol from corn starch and the capital cost of dry mill ethanol plants have decreased. In 1978, ethanol was estimated to cost \$2.47 per gallon to produce (in year 2000 dollars). ${ }^{11}$ By 1994 this price had dropped to $\$ 1.43$ per gallon ${ }^{12}$ and current fuel ethanol production costs are estimated by the authors to be about $\$ 0.88$ per gallon for dry mill operations. The cost reductions may be traced to various factors. The production of ethanol has become less energy intensive due to new techniques in energy integration and the use of molecular sieves for ethanol dehydration. The amount of pure ethanol produced from a bushel of corn has increased from 2.5 gallons to more than 2.7 gallons.

The capital costs of dry mill ethanol plants have also decreased. In 1978 Katzen reported costs for a 50 million annual gallon plant to be about \$2.07 per annual gallon in current dollars. Today new ethanol plants with the necessary utilities are estimated to cost between $\$ 1.25$ and $\$ 1.50$ per annual gallon.

Ethanol production costs and profitability vary within the industry. Ethanol plants range in size with rated yearly capacities from 1 or 2 million gallons to several hundred million gallons. The larger facilities can achieve economies of scale, but other factors enter into the cost of producing ethanol. Producers located near corn growers have the advantage of lower shipping costs to their plants. Producers located near animal feed lots can ship portions of their animal feed co-products in a wet form and eliminate the costs associated with drying wet stillage. Producers located close to markets for $\mathrm{CO}_{2}$ can sell the $\mathrm{CO}_{2}$ generated in their fermentors while other producers must vent it to the atmosphere. Tax credits are given in some, but not all states, to ethanol producers that meet varying size requirements or other restrictions. ${ }^{13}$

\section{II.2 Status of Lignocellulose-to-Ethanol Process}

Conversion of lignocellulosic biomass to ethanol has not yet been demonstrated at commercial scale. Research on this emerging conversion technology began in the 1970s in response to the same oil crisis that spawned the corn ethanol industry. The realization that oil reserves would someday run out gave birth to the idea of a renewable energy pool, one that could be made from either unlimited resources like the sun or wind, or from replenished resources, like crops. Because there is no operating plant for processing lignocellulose to ethanol, the process design and costing is based on lab and pilot scale data, cost estimations of similar industries, and vendor knowledge of equipment design. This obviously increases the margin for cost uncertainty compared to the established corn ethanol industry.

NREL and other organizations, with funding from DOE, is researching this process. In addition, many universities and private corporations are working to understand and integrate the complex process pieces. Corn ethanol industry experts provide invaluable help to further this technology, providing insights gained through decades of ethanol production. 
In order to compare the emerging lignocellulose-to-ethanol process with the commercial corn starch-to-ethanol process, it was assumed that the lignocellulose plant was an $\mathrm{N}^{\text {th }}$ generation plant, built after the industry had been sufficiently established to provide verified costs. This places the lignocellulose plant on a similar level with the established corn ethanol industry, whose costs are well known. This means that additional costs for risk financing, longer start-ups, and other costs associated with first-of-a-kind or pioneer plants are not included. This assumption allows for a process design with less redundancy of systems; however, it should be noted that the estimation error is still greater than for a process design based on established plant data and costs. From this analysis, the capital cost per gallon of fuel ethanol is estimated at almost $\$ 5.44$ for the lignocellulose plant. Some of this cost is due to the higher complexity of the lignocellulose conversion process. A more accurate comparison is with the early corn ethanol industry. The cost of corn ethanol plants has dropped since the industry's inception, and it is realistic to assume that the lignocellulosic ethanol plant costs would also be reduced as more plants are built.

For the lignocellulose process, elimination of some of the capital-intensive areas, through purchase of the materials, could significantly reduce the capital cost. For example, in this analysis enzyme is produced on-site for the lignocellulose process and purchased for the starch process. This contributes about $\$ 0.70$ per gallon in capital costs. Another area is steam production. The lignocellulose plant produces steam from lignin-rich solid residue, which requires a more expensive boiler than natural gas combustion for the starch process. The solids boiler system contributes about $\$ 1.40$ per gallon in capital costs to the lignocellulose process. If the lignocellulose plant were able to locate next to a power generator, steam and electricity could be purchased rather than produced.

For a larger capacity plant, the capital cost per gallon decreases due to the fact that capital costs are not linear with plant capacity. A plant with two times the capacity, or 50 million annual gallons, would have closer to $\$ 4.30$ per gallon in capital costs. The cost to transport feed from a longer distance to supply the larger plant might offset some of these savings.

In contrast, one could model the lignocellulosic ethanol plant as a pioneer plant, the first of its kind, in which case the costs would be significantly higher due to the higher level of uncertainty in the design and costing. There are methodologies discussed in literature to build this type of model which might provide a more accurate cost estimate in the design and construction phases of the first plants. ${ }^{14}$ The method compares a fledging technology with an established similar one, taking into account how much of the technology is new and how much is proven. Depending on this "new to proven" ratio, a factor is applied to the cost estimates to account for the additional costs associated with the new technology. Applying these factors, while increasing the cost estimate, may provide a more accurate estimate earlier, and help avoid cost creep during the construction and startup phases. 


\section{Process Descriptions}

Each process has the same general flow, from feedstock handling through fermentation to product and co-product recovery. The process details are outlined below.

\section{III.1 Corn Starch Feedstock-to-Ethanol Process Description}

Figure 1 depicts the dry mill process. The majority of the flowsheet information was provided by Delta-T Corporation, which designs, constructs, and operates corn ethanol plants. ${ }^{15}$

Figure 1. Corn starch-to-ethanol dry mill process flow

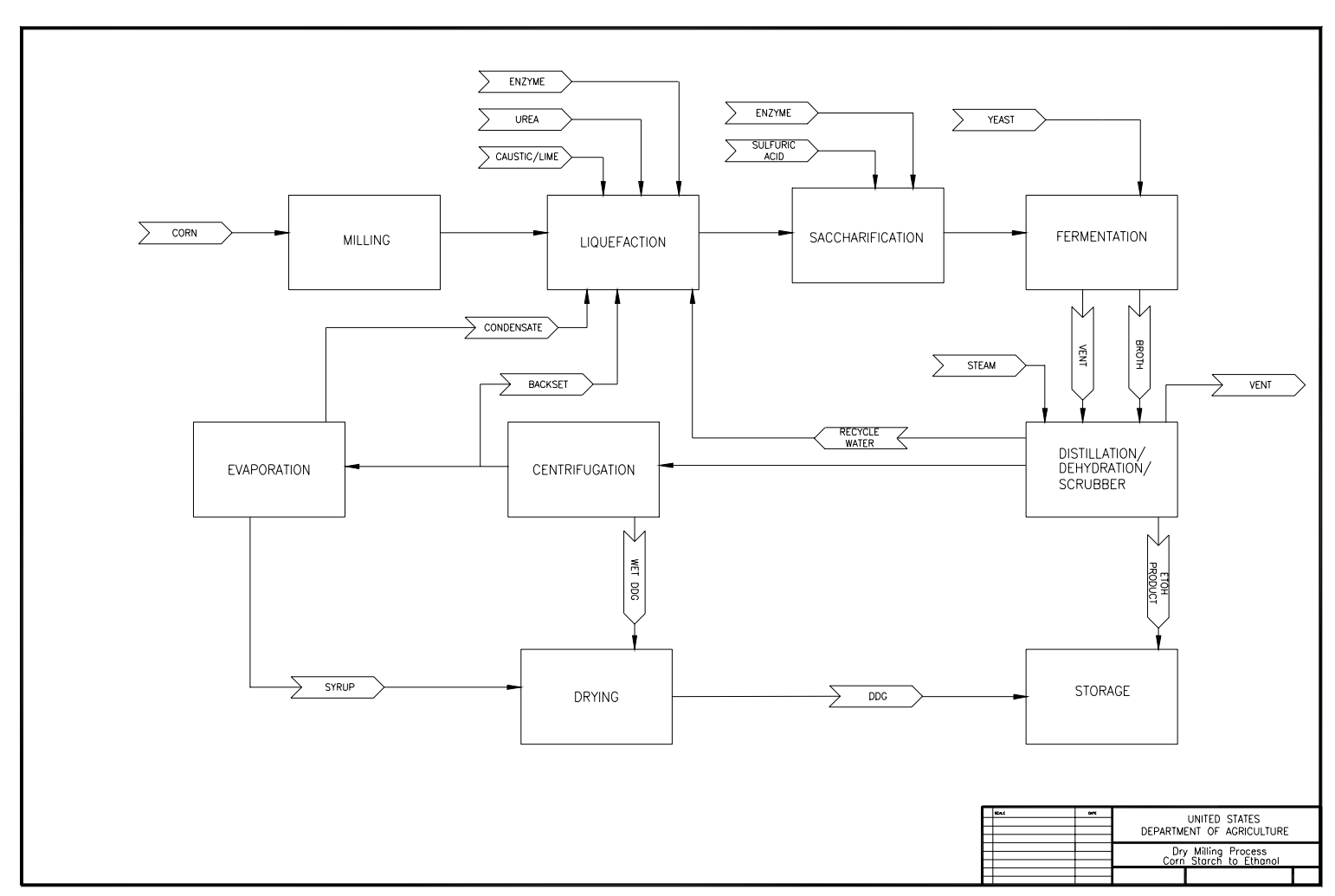

Corn is received and conveyed to two storage silos, having a combined capacity of 10 days. Stored corn is conveyed to grain-cleaning equipment where trash such as tramp metal and rocks $(0.3 \%)$ is removed, and then to hammer mills (two operating mills, plus one standby). The corn meal is metered to a continuous liquefaction tank, where it is mixed with hot evaporator condensate and purchased alpha-amylase enzyme. The condensate is heated with steam to maintain $88^{\circ} \mathrm{C}\left(190^{\circ} \mathrm{F}\right)$ in the tank. Used caustic from the clean-in-place system and lime are also added to provide optimum $\mathrm{pH}(6)$ and calcium for the alpha-amylase. Urea is added to provide nitrogen to the yeast fermentation. After liquefaction, backset (recycled thin stillage from the centrifuge) is added, amounting to $15 \%$ by volume of the final mash. Then the mash is heated to $110^{\circ} \mathrm{C}$ $\left(230^{\circ} \mathrm{F}\right)$, held for 20 minutes, and cooled to $60^{\circ} \mathrm{C}\left(140^{\circ} \mathrm{F}\right)$. Continuous saccharification takes place in a stirred tank where purchased glucoamylase is added with sulfuric acid for 
$\mathrm{pH}$ control (4.4). Residence time in the saccharification tank is 6 hours. The saccharified mash is cooled to $32^{\circ} \mathrm{C}\left(89^{\circ} \mathrm{F}\right)$ and fed to four continuous cascade fermentors where yeast is added. Total residence time in the fermentors is 46 hours. Temperature is maintained below $34^{\circ} \mathrm{C}\left(93^{\circ} \mathrm{F}\right)$ by recirculation through two external heat exchangers, and $\mathrm{pH}$ is maintained above 3.5. Recirculating the off-gas through a compressor mixes the airlift fermentors. The concentration of ethanol in the whole beer leaving the fermentors is $9 \%$ by weight ( $12 \%$ by volume).

In liquefaction, the alpha-amylase attacks the starch polymer randomly, producing maltose (di-glucose) and higher oligomers. In saccharification, the gluco-amylase attacks the non-reducing end of maltose and higher oligomers, splitting off glucose. In addition to the alpha 1-4 linkages, there are alpha 1-6 branch points. These are attacked by pullulanase. This enzyme is probably found as a minor constituent of commercial enzymes, which are not pure enzyme preparations, but complex mixtures. The latest development in dry-mill ethanol enzymes is alpha amylase containing some protease that makes some of the corn protein available for yeast nutrition.

The whole beer is heated, degassed, and fed to the beer column. Steam and cooling water for heating and cooling of the mash, whole beer, and whole stillage are conserved by the use of heat recovery exchangers. Fermentor off-gas and vapors from degassing the whole beer are sent to a water scrubber where ethanol vapor is removed and recycled. The scrubbed $\mathrm{CO}_{2}$ is released to the atmosphere. The whole stillage leaves the bottom of the beer column at less than $0.1 \%$ by weight ethanol. The overhead vapors pass to the bottom of the rectifier, where the concentration of ethanol is increased from $45 \%$ to $91 \%$ by weight. The bottoms from the rectifier are pumped to the top of the stripper. The bottoms from the stripper (less than $0.1 \%$ by weight ethanol) are recycled to the liquefaction tank along with evaporator condensate. The concentrated vapor from the rectifier is superheated and passes through one of two dehydrating molecular sieve beds; one is used while the other is regenerated. Vapors from the regenerated bed are condensed and recycled to the rectifier. The superheated vapor passing through the molecular sieve bed contains more than $99 \%$ by weight ethanol. The product is condensed, cooled, stored, denatured with gasoline ( $5 \%$ by volume), and shipped. Ethanol storage capacity is 12 days.

The whole stillage is partially evaporated in the first three stages of a six-effect vacuum evaporator. The partially evaporated whole stillage is separated in a decanter centrifuge (one operating plus one standby). The wet grains leave the centrifuge at $35 \%$ by weight total solids. The thin stillage from the centrifuge is partially recycled as backset, and the remainder is concentrated in the final three stages of the evaporator to syrup containing $55 \%$ by weight total solids. To conserve steam and cooling water, the condensation of overhead vapors from the rectifier to provide reflux for distillation is accomplished in the evaporator. The syrup and wet grains are mixed and dried in a gas-fired rotary dryer. The DDG leaving the dryer contains $9 \%$ moisture by weight. The process is designed to be essentially zero-discharge. Makeup water is added only for the cooling tower and the $\mathrm{CO}_{2}$ scrubber, and no wastewater is produced. 


\section{III.2 Lignocellulose Feedstock-to-Ethanol Process Description}

The process used in this analysis can be briefly described as using co-current dilute acid prehydrolysis of the lignocellulosic biomass with simultaneous enzymatic saccharification of the remaining cellulose and co-fermentation of the resulting glucose and xylose to ethanol. In addition to these unit operations, the process involves feedstock handling and storage, product purification, wastewater treatment, enzyme production, lignin combustion, product storage, and other utilities. In all, the process is divided into nine areas (see Figure 2). Details of the process can be found in the NREL design report for the dilute acid prehydrolysis and enzymatic hydrolysis process. ${ }^{16}$

Figure 2. Lignocellulose-to-ethanol process flow

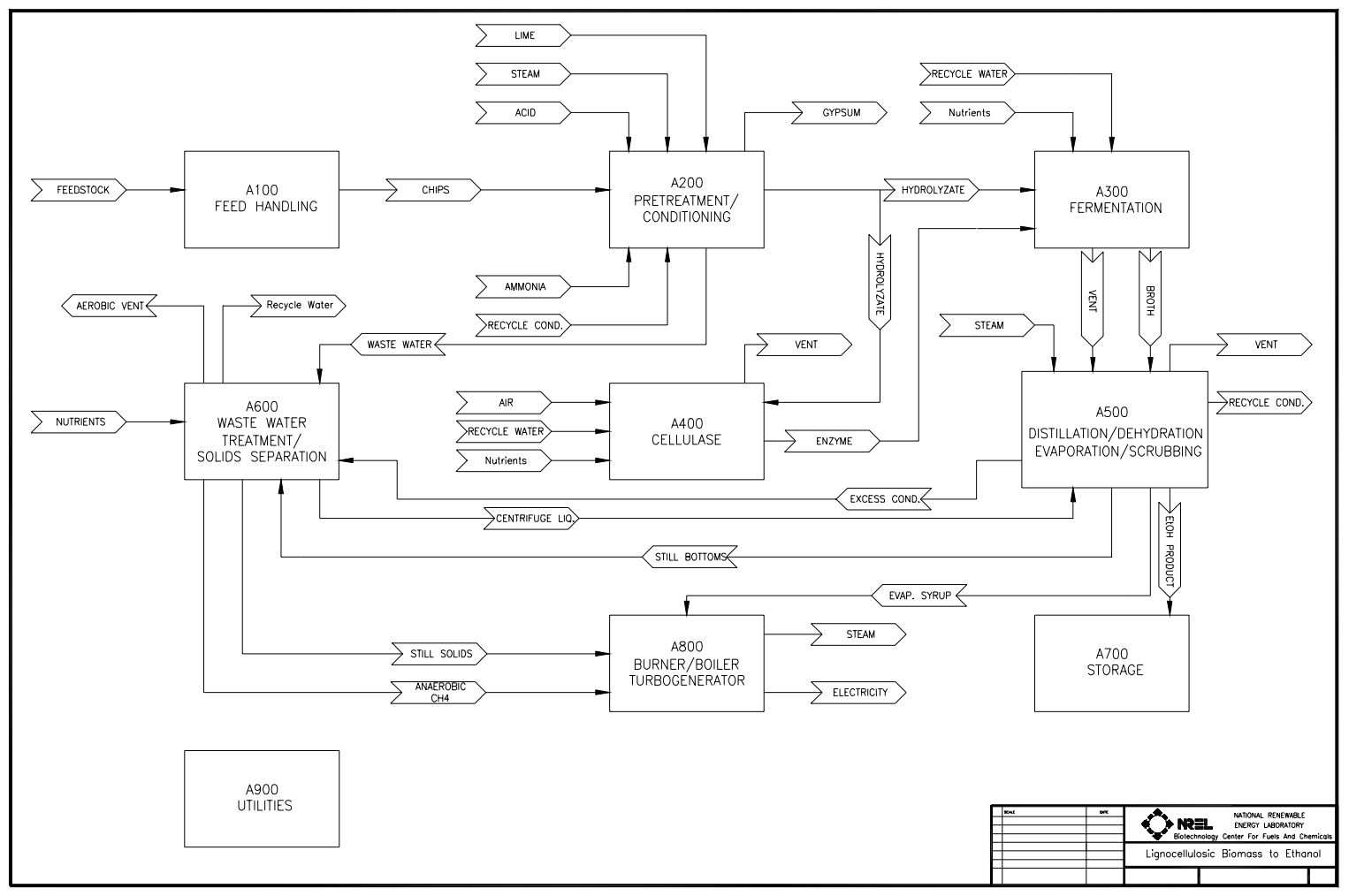

The feedstock, in this case corn stover, is delivered to the feed handling (A100) area for storage and size reduction. From there, the biomass is conveyed to pretreatment and conditioning (A200). In this area, the biomass is treated with dilute sulfuric acid at a high temperature for a very short time, liberating the hemicellulose sugars and other compounds. Ion exchange and overliming is required to remove compounds liberated in the pretreatment that will be toxic to the fermenting organism. Only the liquid portion of the hydrolysis stream is conditioned.

After pretreatment, a portion of the hydrolyzate slurry is split off to enzyme production (A400). In enzyme production, seed inoculum is grown in a series of progressively larger aerobic batch fermentors. The inoculum is then combined with additional hydrolyzate 
slurry and nutrients in aerobic fermentors to produce the enzyme needed for saccharification.

Simultaneous saccharification and co-fermentation, or SSCF, (A300) of the hydrolyzate slurry is carried out in a series of continuous anaerobic fermentation trains. The recombinant fermenting organism Zymomonas mobilis is grown in progressively larger batch anaerobic fermentations. This inoculum, along with cellulase enzyme from enzyme production (A400) and other nutrients, is added to the first fermentor. After several days of saccharification and fermentation, most of the cellulose and xylose will have been converted to ethanol. The resulting beer with $4-5 \%$ by weight ethanol is sent to product recovery.

Product recovery (A500) consists of a beer column to distill the ethanol from the majority of the water and residual solids. The vapor exiting the beer column is $35 \%$ by weight ethanol and feeds the rectification column. A mixture of nearly azeotropic $(92.5 \%)$ ethanol and water from the rectification column is purified to pure $(99.5 \%)$ ethanol using vapor-phase molecular sieves. The beer column bottoms are sent to the first effect of a three-effect evaporator. The rectification column reflux condenser provides heat for this first effect. After the first effect, solids are separated using a centrifuge and dried in a rotary dryer. A portion (25\%) of the centrifuge effluent is recycled to fermentation and the rest is sent to the second and third evaporator effects. Most of the evaporator condensate is returned to the process as fairly clean condensate (a small portion, $10 \%$, is split off to waste water treatment to prevent build-up of low-boiling compounds) and the concentrated syrup contains $15 \%-20 \%$ by weight total solids.

Biogas (containing 50\% methane, and with a heating value of approximately 12,000 British thermal units, or Btu, per pound) is produced by anaerobic digestion of organic compounds in wastewater treatment. The treated water is considered suitable for recycling and is returned to the process, so there is no water discharge from the process.

The solids from distillation, the concentrated syrup from the evaporator, and biogas from anaerobic digestion are combusted in a fluidized bed combustor, or FBC, (A800) to produce steam for process heat. Soluble components in the wet boiler feed are combusted and some water vapor exits through the stack. The majority of the steam demand is for the pretreatment and distillation areas. Generally, the process produces excess steam that is converted to electricity for use in the plant; any excess electricity is sold to the local power grid.

\section{III.3 Primary Process Differences}

There are some major differences in the processing of corn starch versus stover. Stover requires more feed handling; it is envisioned that stover will be delivered in bales that must be washed, shredded, and then milled to achieve a particle size that can be conveyed to the process. Corn requires milling to a fine meal. The steps to reduce the carbohydrate polymers in stover to simple sugar monomers take considerably longer and are more energy intensive than for the starch in corn. The cellulose requires pretreatment 
approaching $180^{\circ}-200^{\circ} \mathrm{C}\left(356^{\circ}-392^{\circ} \mathrm{F}\right)$ with dilute acid to make the cellulose digestible by cellulase enzyme versus $80^{\circ}-90^{\circ} \mathrm{C}\left(176^{\circ}-194^{\circ} \mathrm{F}\right)$ for cooking the corn starch. After pretreatment, the cellulase enzyme and fermentation organism require about 7 days for conversion to ethanol, compared to 2 days for starch. The longer residence time increases the chance for contamination during SSCF. The resultant beer is more dilute, and the mixing power requirements are higher due to a higher solids content. Starch is converted using two main enzymes, alpha-amylase and gluco-amylase. These enzymes have improved over the years, and now convert essentially $100 \%$ of the starch to glucose, provided that the corn is finely ground and properly cooked.

The residual solids from each process have value as a by-product. The DDG is high in protein and is sold for animal feed. The lignocellulosic residue has no food value but has a high energy value and can be used for fuel. Table 2 shows the composition of the DDG and lignocellulosic residue and their relative amounts for a 25 million annual gallon fuel ethanol plant. The lignocellulosic residue composition is determined in the process model. It should be noted that ethanol and possibly electricity are the only products of the lignocellulose plant considered here. Certainly, smaller-volume niche products will emerge - products that can also be produced from the lignocellulose-derived sugars and that will have a significantly higher profit margin. This is also true for the starch process; higher value co-products such as zein proteins and corn fiber-based products are under study by the USDA. When these other products and their selling prices are figured into the analysis, the cost of fuel ethanol will decrease, just as the cost of gasoline is lowered by the sale of other petroleum products of crude oil.

Table 2. DDG and Lignocellulosic Residue Composition and Production

\begin{tabular}{|l|r|l|r|}
\hline \multicolumn{1}{|c|}{ DDG $^{17}$} & \% As-is Basis & Lignocellulosic Residue & \% As-is Basis \\
\hline \hline Neutral Detergent Fiber & 44.0 & Cellulose & 4.6 \\
\hline Protein & 27.0 & Hemicellulose & 3.6 \\
\hline Fat & 9.0 & Lignin & 12.3 \\
\hline Ash & 5.0 & Protein & 1.7 \\
\hline Other (glycerol, other organics) & 6.0 & Other Organics & 14.7 \\
\hline Moisture & 9.0 & Ash & 4.5 \\
\hline Total & 100.0 & Moisture & 58.6 \\
\hline & & Total & 100.0 \\
\hline \multicolumn{2}{|r|}{} & 243.6 & Tons per day at 58\% moisture \\
\hline Tons per day at 9\% moisture & 6.4 & Pounds per gallon fuel ethanol & 1481 \\
\hline Pounds per gallon fuel ethanol & \multicolumn{2}{|c|}{39.1} \\
\hline
\end{tabular}

\section{Normalization of Design and Economic Models}

A large part of this joint effort was to put the two models, developed separately, on common design and costing bases. While not a trivial effort, it was encouraging to find that much of the design assumptions and costing methodologies were, though not identical, definitely comparable. In 1999, NREL completed a comprehensive review of its design and costing with Delta-T Corporation, which designs, constructs, and operates corn ethanol plants. ${ }^{15}$ The majority of the costs used in the USDA process model were also from Delta T. USDA and NREL staff evaluated the physical properties, equipment specifications and costs, and operating costs. When necessary, modifications to one or 
both models were discussed and agreed upon. It was agreed that some differences would remain, particularly in modeling the utilities, to aid in combining the two models later.

Both the USDA and NREL use ASPEN Plus ${ }^{\mathrm{TM}},{ }^{18}$ a chemical engineering simulation software package to model the mass and energy balances for both of the ethanol processes, and Microsoft Excel ${ }^{\mathrm{TM}}$ for creating costing and economic analysis models. In order to make the comparison, both portions of the models had to be aligned. This alignment ensured that the models used similar assumptions and rigor in both process and economic calculations. By-products of this alignment were simplified ASPEN Plus and Excel versions of the NREL lignocellulose process model that were less complex and more user friendly. This simpler model provides the same results as the more rigorous version.

\section{IV.1 History of the Models}

\section{IV.1.1 Starch Model}

A process and economic model of a dry milling ethanol facility was developed several years ago by the USDA-ARS to assist researchers in reducing the cost of ethanol from corn. This model, incorporated in commercial process simulation software, ASPEN Plus, was based on data from ethanol producers, engineering firms, equipment manufacturers, and a USDA-sponsored study. ${ }^{19}$ This model includes process flows, details of the capital and operating costs of the equipment, raw materials, utilities, and the co-products involved in ethanol production. This model has served as a base case to evaluate the cost advantages of various process alternatives such as continuous high-gravity fermentation with stripping. ${ }^{20}$

\section{IV.1.2 Lignocellulose Model}

A process and economic model of the conceptual lignocellulose-to-ethanol process was initially developed by NREL in 1995. A database of physical properties for the components of lignocellulosic feedstocks was developed. ${ }^{21}$ The rigorous ASPEN Plus model was developed to help the DOE Biofuels program direct research in the development of ethanol from lignocellulosic feedstocks in two ways. Modeling the process and its economics provides an objective way to evaluate research ideas and results, and it also provides DOE with process economic details about the lignocellulose process. The model has been refined each year by NREL engineers with data obtained through formal subcontracts with engineering construction firms and vendors, and informal contact with the corn ethanol industry, culminating in the design report, published in 1999. ${ }^{16}$ The methodology for design and costing of the lignocellulose-toethanol process is outlined in this report and the process design and model described was the starting point for the creation of the simplified model used for this project. Assumptions about yields, operating conditions and other process design parameters for this study were taken from the Best of Industry case in the above referenced report. 


\section{IV.2 Methodology for Achieving the Same Basis}

Because the primary goal of this work was to compare the two processes' economics, it was necessary to align model methodology. This included normalizing inputs to the ASPEN Plus model and the economic spreadsheet. In ASPEN Plus, the components, unit operations, physical properties and model rigor, and complexity were compared. The NREL model was simplified to make its evaluation easier. In the Excel spreadsheet, the costing methods and cost scaling methods were aligned. The Excel workbooks were made more user-friendly with simple variables like plant life, cost year basis, and feedstock cost inputs that can be changed by the Excel user. The power consumption calculations in both models were moved to Excel to make them more accessible to the user, both for review and for changing the inputs, such as when calculating power usage for mixing.

\section{IV.2.1 General Economic Parameters}

The plant size was set at 25 million annual gallons of fuel ethanol (consisting of $95 \%$ by volume ethanol and 5\% by volume gasoline denaturant) and the online time was set at 330 days per year for each process. ${ }^{19}$ The year 1999 was chosen as the basis for costs. Indices from the Bureau of Labor, ${ }^{22}$ Stanford Research Institute, ${ }^{23}$ and the Chemical Engineering Plant Cost Index ${ }^{24}$ were used to ratio the labor, chemical, and equipment costs, respectively, from their reference year to 1999. Table 3 outlines the overall parameters that were used in each model. For the analysis done here, the annual production cost, in dollars per gallon of fuel ethanol, is the final comparison tool. The annual production cost includes equipment straight-line depreciation for the life of the plant, and variable costs, labor, supplies and overhead, minus any by-product credits. The market selling price minus the annual production cost is the before-tax profit.

Table 3. General Parameters

\begin{tabular}{|l|c|c|}
\hline & Starch Process & Lignocellulose Process \\
\hline \hline Process & Dry mill & $\begin{array}{c}\text { Dilute Acid/Enzymatic } \\
\text { Hydrolysis }\end{array}$ \\
\hline Feedstock & corn & corn stover \\
\hline Plant Feed rate (dry ton/day) & 633 & 1050 \\
\hline Plant Type & \multicolumn{2}{|c|}{ stand alone } \\
\hline Location & \multicolumn{2}{|c|}{ undetermined } \\
\hline Annual Fuel Ethanol Production (MM gal) & \multicolumn{2}{|c|}{25} \\
\hline On-stream Days & \multicolumn{2}{|c|}{330} \\
\hline Year for cost basis & \multicolumn{2}{|c}{} \\
\hline${ }^{\text {a }}$ million gallons & \\
\hline
\end{tabular}

\section{IV.2.2 Capital Costs}

Equipment costs were obtained from vendor quotations whenever possible, especially for uncommon equipment such as pretreatment reactors or ion exchange equipment, or when 
a complete vendor package could be specified, such as the molecular sieve system. These costs reflect the base size for which the equipment was designed. If process changes were made and the equipment size changed, the equipment was not generally recosted in detail. Using the following exponential scaling expression, the cost was determined by scaling based on the new size or some other characteristic related to the size. Both process models used this ratio method.

New Cost $=$ Original Cost $\left(\frac{\text { New Size }}{\text { Original Size }}\right)^{\text {exp }}$

* or characteristic linearly related to the size

The USDA value of 0.6 for the scaling exponent was selected for this joint effort, which compared to NREL's average value of 0.63 . A range of 0.6 to 0.7 is commonly cited in cost estimation literature. ${ }^{25}$

The size and purchased equipment costs for tanks, heat exchangers, and columns for each process were compared to determine if similar costs were emerging from the different costing methods, which included Richardson Estimating Standards ${ }^{26}{ }^{26}$ vendors, and cost estimating software such as Icarus Questimate ${ }^{\mathrm{TM}^{27}}$ and Chemcost ${ }^{\mathrm{TM}}{ }^{28}{ }^{28}$ Selected results are shown in Figure 3 and Figure 4. In general, there was good correlation in the costs between the two models. The tank costs varied the most, due to the different kinds of tanks used in both processes.

The USDA's experience in the corn industry showed that a factor of 3.0 was reasonable for going from purchased equipment costs to total project investment, while NREL's installation costing method produced a factor of 2.5 , so 2.75 was used for both processes.

Figure 3. Comparison of starch and lignocellulose process stainless steel tank cost

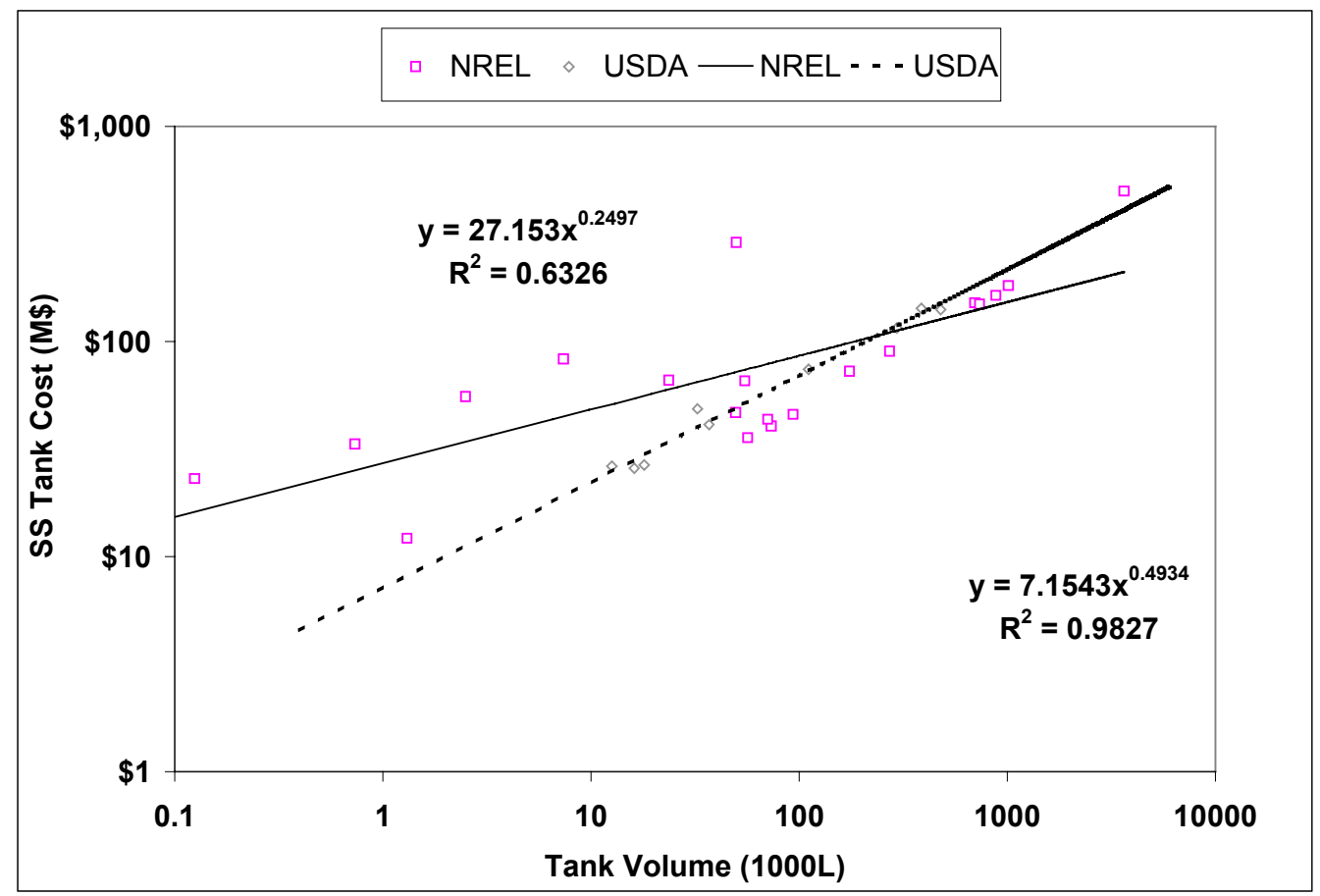


Figure 4. Comparison of starch and lignocellulose process heat exchanger cost

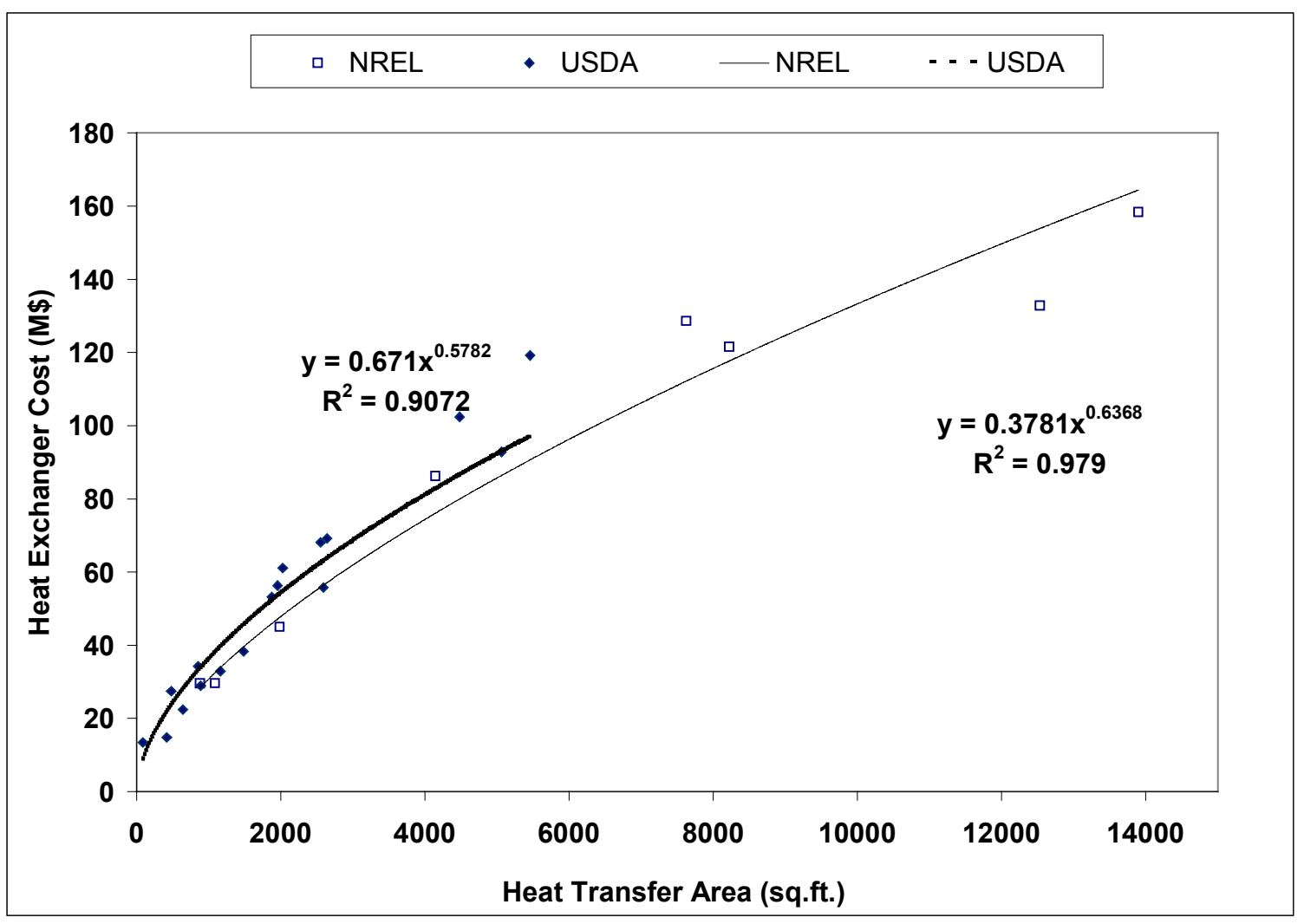

\section{IV.2.3 Variable Operating Costs}

Variable operating costs, such as chemical costs used in both processes, were generally taken from the Chemical Marketing Reporter. Denaturant cost came from DOE's Energy Information Administration. ${ }^{29}$ Chemicals particular to each process, such as enzymes for the starch process or wastewater treatment chemicals, were not changed. Feedstock costs were $\$ 1.94$ per bushel for corn, and $\$ 35$ per dry ton for stover. Electricity was assumed to have the same cost and credit, $\$ 0.04$ per kilowatt-hour $(\mathrm{kWh})$. The starch process purchases electricity, while the stover process produces excess, which is considered a saleable by-product.

\section{IV.2.4 Labor, Supplies, and Overhead}

Labor, supplies, and overhead (sometimes termed fixed operating costs) were normalized based on several references, including recent subcontract work through DOE, "Building a Bridge to the Corn Ethanol Industry.", ${ }^{, 2,3}$ Most notably, two separate engineering firms suggested a ratio of one maintenance person for every two to three operators. Operating and maintenance supplies, overhead and taxes, and insurance were calculated based on literature references. ${ }^{30,31,32}$ No state or federal tax credits, nor small producer credits or incentives were assumed for either process. 


\section{Changes Required in the Process Models}

USDA-ARS or NREL staff made specific changes to the corn starch or lignocellulose model, respectively. Joint review of the models allowed the participants to provide input to both models, which resulted in a better understanding for all involved and models that were easy to use and understand.

\section{V.1 Starch Model}

\section{V.1.1 Changes Made to the Starch Model and Other Work}

1) Production capacity was normalized at 25 million annual gallons of fuel ethanol. The original USDA model addressed a facility with a production capacity of 15 million annual gallons.

2) The costs of raw material and chemicals, where applicable, were put on the same basis for both facilities. Yeast, urea, and enzymes are examples of purchased raw materials unique to the starch process.

3) Plant labor charges were examined for both facilities and placed on a consistent basis. The corn starch-to-ethanol facility has five operators and two maintenance personnel per shift.

4) The cost for the steam generation equipment and the cooling towers were removed from the capital cost portion of the estimate to accommodate future integration of the utilities between the lignocellulose-to-ethanol facility and the corn starch-to-ethanol facility. These utilities were treated as purchased items and their cost included in the utility cost section of the operating costs. The steam cost was based on the capital and operating costs of a gas-fired boiler, which includes natural gas cost.

5) The calculations to determine the operating and capital costs of the corn starch-toethanol facility were removed from the ASPEN Plus simulation program and placed in an Excel spreadsheet.

\section{V.2 Lignocellulose Model}

\section{V.2.1 Lignocellulose Model Changes and Other Work}

1) Production capacity was normalized at 25 million annual gallons of fuel ethanol. The original NREL model addressed a facility with a production capacity of 56 million annual gallons.

2) The simplified ASPEN Plus model has 40\% fewer model components (unit operations, process streams, or control blocks) than the original model. The overall model is thermodynamically rigorous and uses built-in physical properties as well as properties developed at NREL. The individual unit models are thermodynamically 
consistent and can be either rigorous (for example, the simulation of the distillation) or simple.

3) The physical properties for the lignocellulosic components were added to the model's input language to eliminate the need to access the NREL in-house database with the model.

4) Two major sections were removed from the ASPEN Plus model, wastewater treatment and steam/electricity generation, in anticipation of combining the two models in a co-location scenario. The wastewater treatment section of the model was reduced to an expression that calculates the capital and operating costs and power requirements of the system based on the hydraulic flow and the chemical oxygen demand (COD) of the incoming waste water. Similarly, the fluidized bed combuster and turbogenerator system was replaced with several Fortran expressions to calculate the costs and net power generation from the burner feed streams.

5) The original NREL model linked the Excel spreadsheet with a database containing the base costs and scaling factors for equipment and chemical costs. For this project, the spreadsheet was loaded with data, but not linked to the database.

6) The original NREL model used installation factors unique to equipment types, obtained from literature or vendors, then applied other projects costs (contingency, contractor expenses) to determine a total plant investment cost. The average installation factor was 1.4, and the combined other project costs resulted in an additional factor of 1.76. Combining these two factors resulted in one overall factor of 2.5 that can be applied to the purchased equipment cost to obtain the total project cost. The factor agreed upon, 2.75, was an average of this value and the USDA value of 3 .

7) Estimated labor charges for the stover plant were evaluated against the estimated labor charges for the dry mill. Because the stover process is considered more complex and the feed handling more labor intensive, more operators are needed, as well as more mechanics. The lignocellulose-to-ethanol facility has more processing steps than the corn starch-to-ethanol facility, and costs include ten operators and four maintenance personnel per shift.

8) The total project cost, along with the plant operating expenses was used in the original NREL model in a discounted cash flow analysis to determine the cost of ethanol production, using a set discount rate. The simplified NREL model matched the more rigorous original model within $\$ 0.02$ per gallon production cost using the same discounted cash flow rate of return (DCFROR) method for both. The economic analysis was changed to annual production cost from DCFROR method to place it on the same basis as the corn starch model. This removes the working capital, loan assumptions, and discount rate in the original NREL methodology. 


\section{Production Costs of Fuel Ethanol}

The resulting costs of producing 25 million annual gallons of fuel ethanol from each process were determined from the normalized models. Figure 5 shows the production cost breakdown for each process. Detailed cost information for each process can be found in the Appendix.

Figure 5. Production costs in dollars per gallon of fuel ethanol (1999\$)

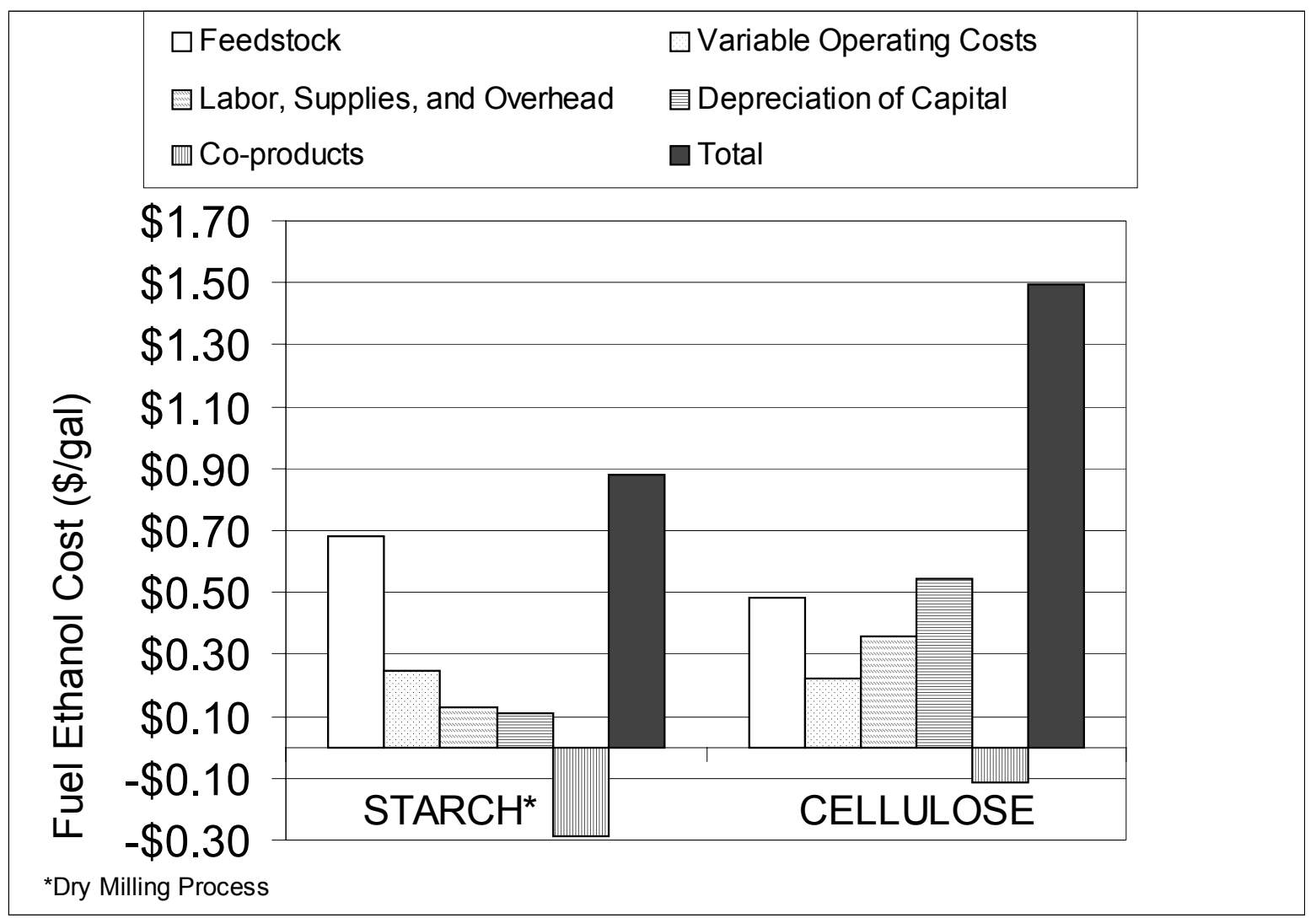




\section{VI.1 Production Costs for the Starch Process}

Table 4 details the production costs, in annual dollars, and in dollars per gallon of fuel ethanol, for the starch process.

Table 4. Production Costs for the Starch Process (1999\$)

\begin{tabular}{|l|r|r|}
\hline & \multicolumn{1}{|c|}{ Annual } & \multicolumn{1}{|c|}{ Per Gallon } \\
\hline \hline Shelled Corn & $\$ 17,000,000$ & $\$ 0.68$ \\
Other Raw Materials & $\$ 1,600,000$ & $\$ 0.06$ \\
Denaturant & $\$ 600,000$ & $\$ 0.03$ \\
Utilities & $\$ 4,000,000$ & $\$ 0.16$ \\
Labor, Supplies, and Overhead Expenses & $\$ 3,100,000$ & $\$ 0.13$ \\
Depreciation of Capital & $\$ 2,800,000$ & $\$ 0.11$ \\
DDG Credit & $-\$ 7,100,000$ & $-\$ 0.29$ \\
Total Production Cost & $\$ 22,000,000$ & $\$ 0.88$ \\
\hline
\end{tabular}

\section{VI.1.1 Feedstock Costs}

The single greatest cost in the production of ethanol from corn, and the cost with the greatest variability, is the cost of the corn. Corn prices vary from year to year and in the last few years have ranged from $\$ 1.94$ per bushel to $\$ 3.24$ per bushel ( 1 bushel $=56$ pounds). Corn prices will also vary in different locations due to shipping distance from the field to the plant.

A yield of 2.85 gallons of fuel ethanol per bushel of corn (2.71 gallons pure ethanol) was calculated in this study. At a cost of $\$ 1.94$ per bushel the cost of the corn required to produce a gallon of fuel ethanol is $\$ 0.68$. For a dry milling facility that is selling only DDG, the net cost of corn, which is the cost of the corn entering the plant minus any credits received for co-products, is $\$ 0.40$ per gallon of fuel ethanol.

\section{VI.1.2 Gasoline Denaturant}

Fuel ethanol is sold with a $5 \%$ by volume gasoline content in this model. Gasoline contributes about $\$ 0.03$ to the cost of a gallon of fuel ethanol.

\section{VI.1.3 Enzymes, Yeast, and Various Chemicals}

Enzymes, yeast, and various chemicals are required in the ethanol process to convert the corn starch to glucose, ferment the glucose and assist the process at various stages. Enzyme and yeast costs are from an industry source. In the starch model they contribute approximately $\$ 0.045$ to the cost of a gallon of fuel ethanol. The $\mathrm{C}_{6}$ fermenting yeast is purchased for $\$ 0.01$ of the per gallon production cost. 


\section{VI.1.4 Utilities}

The ethanol dry milling process requires power, heat, and cooling to affect the conversion of corn into ethanol. Steam is required to heat the milled corn to convert the starch to sugar and then to distill the ethanol from the ethanol water produced. Natural gas is needed to dry the solid co-products of ethanol, and cooling water is needed to adjust the temperature of process streams. Well water is also used to cool the fermentation tanks. It is assumed that the well water is available at the same temperature year round. Minnesota was the assumed plant location.

\section{VI.1.5 Co-Product Costs}

The traditional co-product in a dry milling facility is DDG. About 6.4 pounds of DDG is produced for each gallon of fuel ethanol. At a sales price of $\$ 0.045$ per pound, DDG can provide about $20 \%$ of the sales income to an ethanol facility.

\section{VI.1.6 Carbon Dioxide}

The fermentation of corn starch into ethanol generates $\mathrm{CO}_{2}$, which has a low economic value and is expensive to move. Most ethanol producers vent $\mathrm{CO}_{2}$ to the atmosphere, although a few ethanol producers are able to sell it. No income from $\mathrm{CO}_{2}$ sales was included in this analysis.

\section{VI.1.7 Capital Costs}

Capital costs by process area are listed in Table 5 for the starch process.

Table 5. Capital Costs by Process Area (1999\$)

\begin{tabular}{|l|r|}
\hline & \\
\hline \hline Feedstock Handling & $\$ 2,600,000$ \\
Saccharification & $\$ 2,300,000$ \\
Fermentation & $\$ 4,600,000$ \\
Distillation & $\$ 5,300,000$ \\
Solid/Syrup Separation/Drying & $\$ 10,500,000$ \\
Storage/Load out & $\$ 1,500,000$ \\
Wastewater Treatment & $\$ 1,000,000$ \\
Air Compressor & $\$ 100,000$ \\
Total Capital Investment & $\$ 27,900,000$ \\
\hline
\end{tabular}

It should be noted that utilities such as steam, electricity, and cooling tower water are purchased in this cost model and the equipment necessary for their generation is not included in the capital cost of the facility. This makes the capital costs lower than the $\$ 1.25-\$ 1.50$ noted earlier.

The total capital investment has been developed from the equipment costs through the use of equipment installation factors, and includes the supply and installation of the 
process equipment and all support material such as piping, electrical, instrumentation, foundations, and buildings for the process equipment. Also included in the total capital investment is the cost of the facilities design and construction management plus a contingency allowance. The total capital investment has been calculated at 2.75 times the purchased equipment costs.

\section{VI.1.8 Labor, Supplies, and Overhead}

These expenses (sometimes termed fixed operating costs) include the cost of personnel and supplies to operate and maintain the facility plus expenses for the plant's administration, insurance, and taxes.

\section{VI.2 Production Costs for the Lignocellulose Process}

Table 6 details the production costs, in annual dollars, and in dollars per gallon fuel ethanol for the lignocellulose process.

Table 6. Production Costs for the Lignocellulose Process (1999\$)

\begin{tabular}{|l|r|r|}
\hline & \multicolumn{1}{|c|}{ Annual } & \multicolumn{1}{|c|}{ Per Gallon } \\
\hline \hline Corn Stover & $\$ 12,100,000$ & $\$ 0.49$ \\
Corn Steep Liquor & $\$ 1,200,000$ & $\$ 0.05$ \\
Other Raw Materials & $\$ 3,000,000$ & $\$ 0.11$ \\
Denaturant & $\$ 600,000$ & $\$ 0.03$ \\
Waste Disposal & $\$ 700,000$ & $\$ 0.03$ \\
Labor, Supplies, and Overhead Expenses & $\$ 8,900,000$ & $\$ 0.36$ \\
Depreciation of Capital & $\$ 13,600,000$ & $\$ 0.54$ \\
Electricity Credit & $-\$ 2,800,000$ & $-\$ 0.11$ \\
Total Production Cost & $\$ 37,300,000$ & $\$ 1.50$ \\
\hline
\end{tabular}

\section{VI.2.1 Feedstock Costs}

The corn stover feedstock is the most expensive raw material by far. A yield of 72 gallons of fuel ethanol per dry ton of corn stover was calculated from the model. At a cost of $\$ 35$ per dry ton, the cost of the corn stover required to produce a gallon of fuel ethanol is $\$ 0.49$. The actual long-term supply price of corn stover is unknown.

\section{VI.2.2 Gasoline Denaturant}

Fuel ethanol is sold with a 5\% by volume gasoline content in this model. The gasoline contributes about $\$ 0.03$ to the cost of a gallon of ethanol.

\section{VI.2.3 Enzyme, Nutrients, and Various Chemicals}

Sulfuric acid, cellulase enzyme (produced on-site), ammonia, and corn steep liquor are required in the ethanol process to convert hemicellulose to xylose, the cellulose to glucose and supply nutrients to the fermentation organism. CSL and other raw material 
costs are $\$ 3.2 \mathrm{MM}$ per year, or $\$ 0.16$ per gallon. The recombinant organism, rZ. mobilis, is grown on site, at a cost of about $\$ 0.026$ per gallon production cost.

\section{VI.2.4 Utilities}

The lignocellulose-to-ethanol process requires electricity, steam, and a cooling water supply. Steam is required in the pretreatment step to solubilize the hemicellulose to xylose and in distillation. Cooling and chilled water is used to adjust the temperature of process streams. Well water is passed through the fermentation heat exchangers to help maintain temperature. Assuming a Midwest plant site, chilled water is used in fermentation during the summer months. Air compressors are needed to supply air to the cellulase production fermentors.

\section{VI.2.5 Co-Product Credits}

Currently, the only co-product assumed from the lignocellulose-to-ethanol process is excess electricity, sold to the grid at $\$ 0.04$ per $\mathrm{kWh}$, providing a significant credit of $\$ 0.11$ per gallon of fuel ethanol. The electricity is produced from a steam turbine in the plant. Because of the site-specific nature of electricity credits, it is difficult to predict exactly what the revenue could be. It is likely to fluctuate by area and time of day, when the credit is higher during peak demand (daytime) hours. The ability to store either the boiler feed or the power generated during off-peak hours would be beneficial in this case.

Finding a use for the lignin other than a boiler fuel would enhance the economics of this process. Converting the lignin to a higher-value co-product like a fuel or chemical is envisioned. To be beneficial, the value of the lignin-derived co-product must be enough to cover the costs of the upgrade process and still supply revenue to the plant to offset the ethanol production costs.

\section{VI.2.6 Carbon Dioxide}

As in the starch process, the fermentation of lignocellulose into ethanol generates $\mathrm{CO}_{2}$. NREL has yet to investigate the possible market value of carbon dioxide from a robust lignocellulose-to-ethanol industry, so it is not included as a co-product.

\section{VI.2.7 Capital Costs}

The capital costs are listed by process area in Table 7. The complexity of the process is evident from the projected $\$ 136 \mathrm{MM}$ total capital investment. The boiler/turbogenerator area is the most expensive, followed by the pretreatment and conditioning area, and enzyme production area. Alternate process designs using a natural gas-fired boiler, which is cheaper, lowers the capital cost but incurs substantial landfill costs for the lignin residue as well as for the cost of the boiler fuel. Research to better understand the pretreatment process is aimed at reducing the reactor cost and eliminating the need for conditioning the hydrolyzate. The feedstock handling area costed here is preliminary for stover. A design for stover handling is being developed with an engineering firm. The 
equipment and labor costs may change from the estimate presented here. The total plant installed cost was developed in the same way as the starch process.

Table 7. Capital Costs by Process Area (1999\$)

\begin{tabular}{|l|r|}
\hline & \\
\hline \hline Feedstock Handling & $\$ 5,400,000$ \\
Pretreatment/Detoxification & $\$ 29,800,000$ \\
Simultaneous Saccharification/Co-fermentation & $\$ 14,400,000$ \\
Cellulase Production & $\$ 18,100,000$ \\
Distillation & $\$ 5,100,000$ \\
Solid/Syrup Separation & $\$ 9,200,000$ \\
Wastewater Treatment & $\$ 9,000,000$ \\
Storage & $\$ 2,100,000$ \\
Boiler/Turbogenerator & $\$ 37,500,000$ \\
Utilities & $\$ 5,500,000$ \\
Total Capital Investment & $\$ 136,100,000$ \\
\hline
\end{tabular}

It should be noted that utilities such as steam, chilled water, and cooling tower water are treated as equipment in this cost model, contributing to the capital cost of the plant rather than the variable operating cost as in the starch model. When the two processes are combined in a co-location scenario, this equipment will provide service to both processes. For now, converting the capital costs for these utilities in the lignocellulose model to dollars per pound of service allows for a direct comparison. Table 8 shows the lignocellulose utilities as dollars per pound of steam and cooling medium for comparison with the starch model. A comparison of the two steam costs shows that for the starch process, the cost is a combination of natural gas fuel and a gas-fired boiler. The FBC, which is used in the lignocellulose process to burn the lignin residue, has higher capital, but no cost is assumed for the lignin, because it is a byproduct of the process that must be disposed of in some way. The cooling water capital costs were from different sources and will be evaluated more closely in the co-location scenario.

Natural gas is typically used in the industry to fire the DDG dryers. It is uncertain why the flue gas from the boiler is not used, although it is possible the flue gas energy is too low or the dryer demand too high. This will be investigated when combining the utilities in the co-location scenario.

Table 8. Utility Costs

\begin{tabular}{|l|r|r|}
\hline & \multicolumn{1}{|c|}{ Starch Process } & \multicolumn{1}{c|}{ Lignocellulose Process } \\
\hline \hline Steam production & purchased for $\$ 4.50 / 1000 \mathrm{lb}$ & generated for $\$ 2.12 / 1000 \mathrm{lb}$ \\
\hline Steam $(\$ /$ gal fuel ethanol) & $\$ 0.085$ & $\$ 0.186$ \\
\hline Cooling Water $(\$ / 1000 \mathrm{lb})$ & $\$ 0.013$ & $\$ 0.0049$ \\
\hline Cooling Water $(\$ /$ gal fuel ethanol) & $\$ 0.009$ & $\$ 0.019$ \\
\hline Chilled Water $(\$ / 1000 \mathrm{lb})$ & $\$ 0.00$ & $\$ 0.055$ \\
\hline Chilled Water $(\$ /$ gal fuel ethanol) & $\$ 0.00$ & $\$ 0.012$ \\
\hline Natural Gas (for DDG dryers) & $\$ 2.95 / 1000 \mathrm{cu} . \mathrm{ft}$. & flue gas used to dry solids to boiler \\
\hline NG (\$/gal fuel ethanol) & $\$ 0.038$ & $\$ 0.00$ \\
\hline
\end{tabular}




\section{VI.2.8 Labor, Supplies, and Overhead}

These expenses include the same items as the starch process. The lignocellulose-toethanol facility has more complex processing steps than the corn starch-to-ethanol facility, and costs include ten operators and four maintenance personnel per shift. The corn starch-to-ethanol facility has five operators and two maintenance personnel per shift. The ratio of maintenance personnel to operators was taken from two separate subcontracts evaluating the lignocellulose process. ${ }^{1,2,3}$

\section{VI.3 Comparison of Costs}

Figure 6 shows that for the same incremental change in feedstock cost, the ethanol production cost is more affected by the corn. This is true because the corn cost is a much larger part of the production cost than stover. For the lignocellulose process, increasing the capital would show the largest increase in production cost. Figures 7 and 8 show the breakdown of production cost for the starch and lignocellulose processes, respectively. Labor, supplies, and overhead were distributed among the process areas based on the percentage of capital each area had. From this comparison, it is easy to see that the starch process is driven by the cost of corn, while the stover process has significant capital investment.

Figure 6. Effect of changing feedstock cost on fuel ethanol production cost

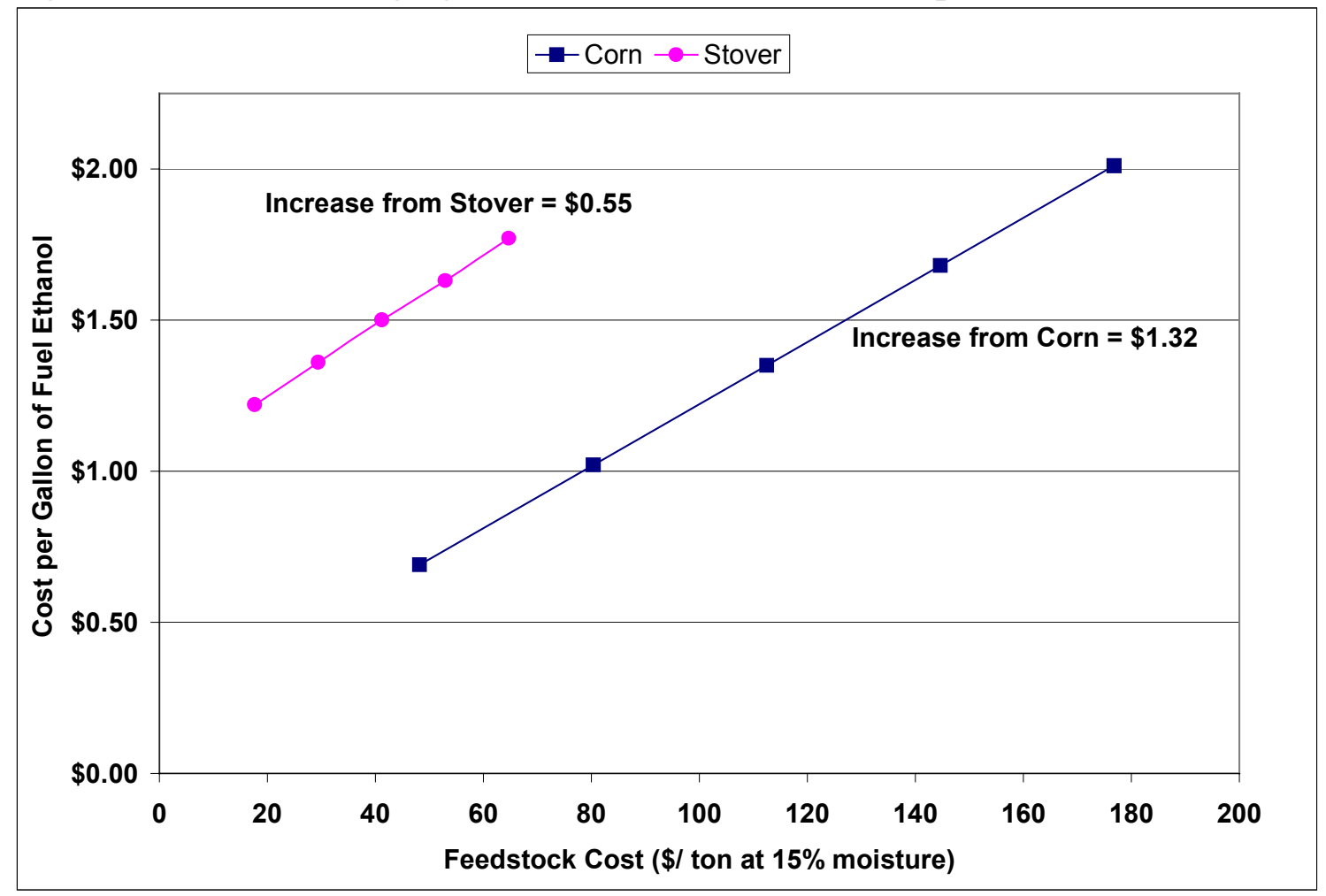




\section{VI.3.1 Starch Costs by Area}

The utilities section appears small because the steam and cooling water capital was converted to variable operating costs and distributed among the areas. Distillation and syrup concentration steps use the most cooling water. Distillation is the primary steam user. This process requires 2,090 kilowatts $(\mathrm{kW})$ of power. Of this demand, $53 \%$ is for the solids separation/drying and syrup evaporation equipment. Fermentation pumps use $7 \%$ of the power, while the hammermills and other grain handling equipment use $8 \%$. Denaturant cost is included in the storage/load-out area, enzymes are included in the saccharification area, and yeast is included in the fermentation area.

Figure 7. Starch costs by process area (1999\$)

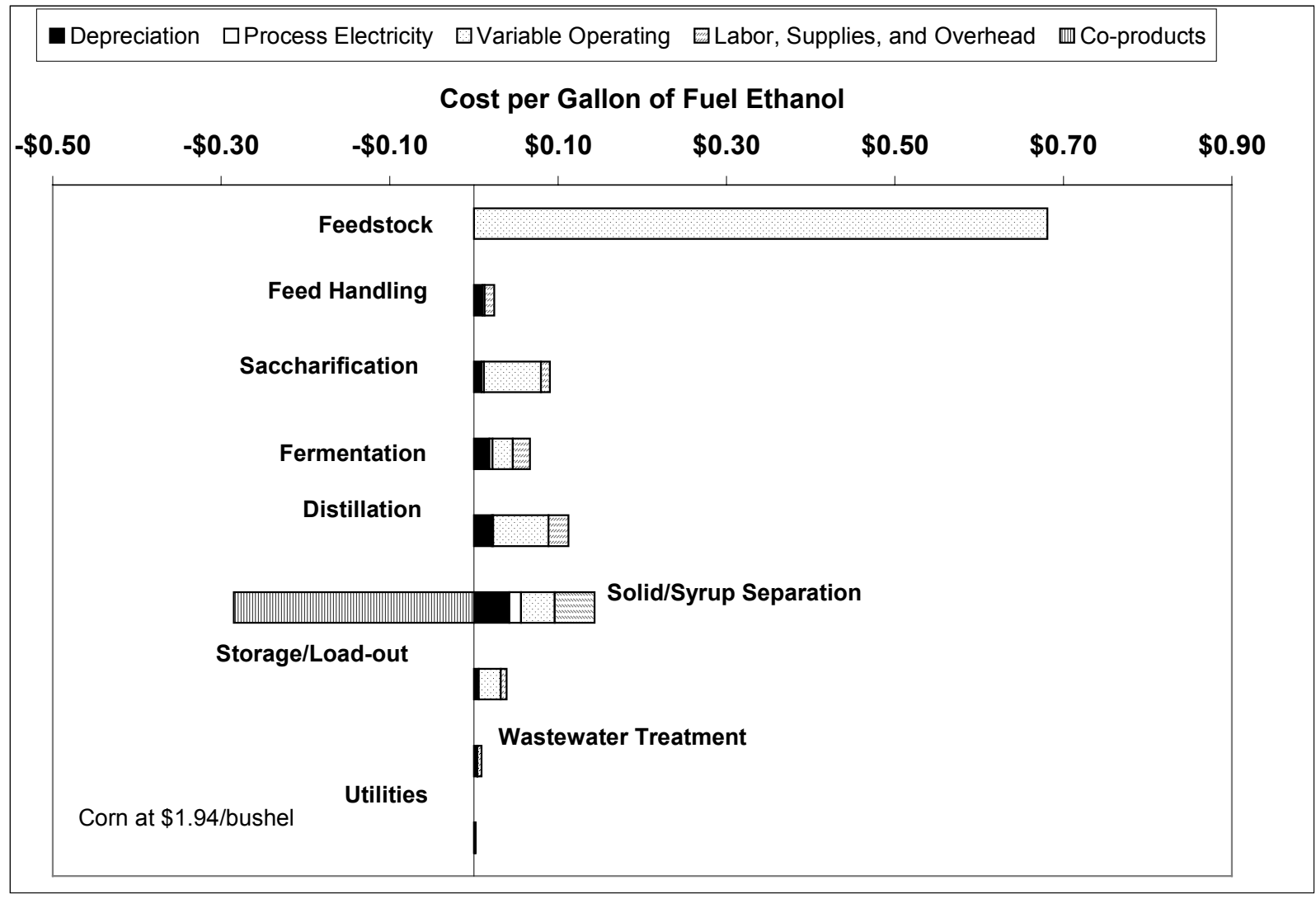

\section{VI.3.2 Lignocellulose Costs by Area}

While not as large as the corn feed costs, the cost for stover feedstock is still significant. In this model, steam costs appear as the largest single area of capital for a FBC and turbogenerator system, and cooling water and chilled water are produced via a cooling water tower and chiller, respectively, which appear in the utilities capital section. For this process, pretreatment is the largest steam consumer, followed by distillation. Enzyme production consumes $32 \%$ of the $9,615 \mathrm{~kW}$ of power used in the plant to compress the air fed to the cellulase fermentors and to agitate the fungal slurry. 
Fermentation requires $15 \%$ of the electricity to agitate and pump the solids-containing slurry. Electricity consumption is estimated from vendor quotes, engineering firm reviews, and comparison with similar applications. While an estimate, it is a rigorous one, including every piece of equipment for the plant down to spares. Comparing the electricity consumption of the two processes, fermentation power is ten times higher in the lignocellulose process due to the higher solids concentration and longer residence time, and there is extensive power usage in the cellulase production area for air compressors. Pretreatment reactors require more power than the mash cookers in the starch process due to solids concentration.

Figure 8. Lignocellulose costs by process area (1999\$)

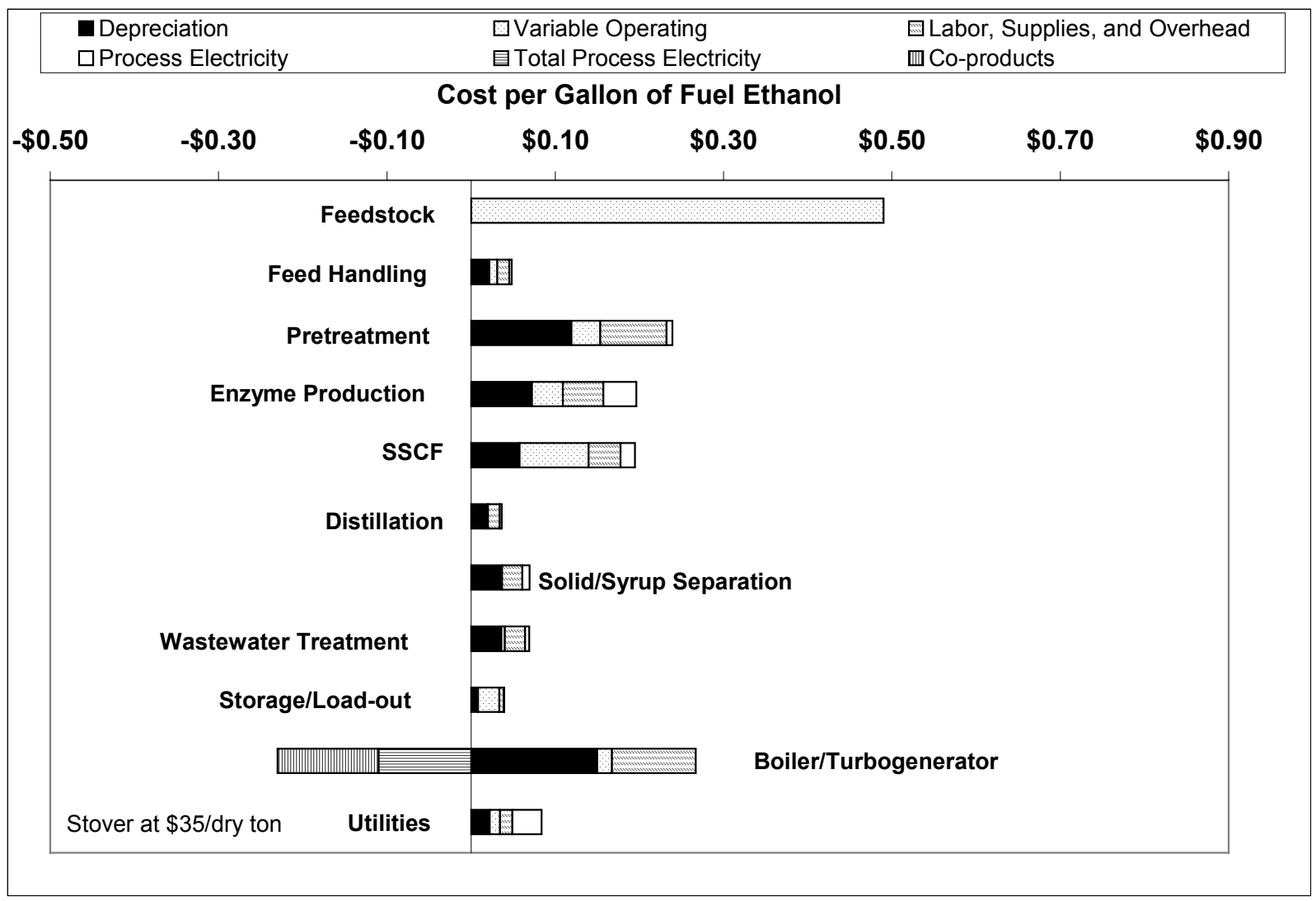

\section{Future Impact of Co-Products}

Co-products can have a substantial impact on the economic viability of a low-value product like ethanol. Changing market environments, regulatory action, and political issues can affect the entire product slate from a plant. Ensuring that a market exists for current and potential co-products after an industry is robust is an important planning exercise in the design of commercial processes. 


\section{VII.1 The Future of Starch Process Co-Products}

\section{VII.1.1 DDG}

As previously stated, DDG is the principal co-product of the dry mill ethanol industry. DDG is $27 \%$ protein and is currently sold as animal feed. Unfortunately, the animal feed markets are now becoming saturated and the price of DDG has dropped from more than $\$ 150$ per wet ton in $1995-1996$ to $\$ 86$ per wet ton in the $1998-1999$ market year. $^{33}$

DDG produced in an ethanol plant can be used for human consumption as long as the original ingredients (corn, enzymes, yeast) are GRAS (generally regarded as safe) and the processing plant is approved for food manufacture. Applications for DDG in the food industry would increase its value and demand, and would also change the design requirements for the process.

Future directions for DDG price and demand remain uncertain.

\section{VII.1.2 Carbon Dioxide}

Fermentation of corn produces approximately equal amounts of $\mathrm{CO}_{2}$ and ethanol. A few ethanol plants capture and sell this $\mathrm{CO}_{2}$, usually to an organization that specializes in cleaning and pressurizing it. For an ethanol producer to sell $\mathrm{CO}_{2}$, a user must be nearby and the amount of $\mathrm{CO}_{2}$ generated must be great enough to justify the cost of the $\mathrm{CO}_{2}$ recovery and purification equipment.

\section{VII.1.3 Corn Germ}

Current practice in most dry milling facilities today is not to degerm the corn but rather have the corn germ (and oil) be included in the DDG. Separation of the corn germ prior to fermentation should add to the profitability of the dry milling process.

\section{VII.2 The Future of Lignocellulose Process Co-Products}

\section{VII.2.1 Electricity}

In the face of deregulation of the electric utility industry, relying on a high value for the excess electricity is difficult. For a plant to consider this a long-term revenue stream, optimizing the generation or sale of the power during peak consumption may be important. Storage batteries, storing boiler feed, banking steam, or employing turndown on the boiler or turbogenerator are all options for matching generation with demand and maximum value. Siting the plant must include negotiations with a power producer, with the hope of a long-term contract. Environmental regulations are different for power generators and there is a balance between ethanol or power generation as the primary function of the plant. The electricity value used in this analysis ( $\$ 0.04$ per $\mathrm{kWh})$ comes from a study performed by an engineering firm for NREL in $1994 .{ }^{34}$ 


\section{VII.2.2 Lignin}

Finding a way to make the lignin residue a higher-value co-product from the lignocellulose process is an important aspect of long-term commercial viability for the process. While it has value as a high/medium energy fuel, it is a new type of solids fuel and there is little demand for it outside of the plant boundaries, and the costs of drying it for transportation only subtract from its potential value. Gasification of the lignin could provide some help in converting it to a higher-value product with lower cost. Chemical or fuel production from lignin may be feasible; however the markets for potential products must be evaluated from both fledgling and mature ethanol industry views.

\section{VII.2.3 Other Co-Products}

Cell matter, furfural, and acetic acid have been identified as potential co-products. Interstitial cell matter could be valuable, but might require significant purification. Markets for furfural and acetic acid are in place, although it is unlikely that they could sustain the effect of a fully commercialized lignocellulose-to-ethanol industry. When looking at co-products, there is the potential for a small market, high-value product to provide a step up for the first few plants. After that, co-products must have large enough markets so that they are not saturated by a mature industry.

\section{Prospects and Challenges for a Combined Process}

In 1998, DOE provided funds to allow corn ethanol producers to investigate the possibilities for producing ethanol from lignocellulose at their facilities. Five companies from the industry teamed with engineering construction firms and other professionals to explore the potential of co-location of cellulosic ethanol with their existing corn ethanol processes. The final reports of five of the six contracts were received in the first quarter of 2000 and technically reviewed by NREL. All of the projects involving corn stover use at a dry mill were deemed unprofitable, with negative or zero return on investment. With reduced enzyme costs, at least one of the corn stover projects would be profitable and potentially a second. The complete reports are available through NREL and a comparison report is due to be issued later in 2000. From this work, the following challenges were identified:

1) Use of the existing plant infrastructure and co-mingling of process steps was not recommended. Use of genetically modified organisms (GMOs) like the rZ. mobilis made combining the lignin solids with the DDG a perceived negative. The presence of lignin in the solids also contributed to this issue. We need to better understand what the issues are surrounding GMO use and its perceived effect on the DDG market and value. Capital was not reduced in these co-location scenarios because the process streams were kept separate virtually the entire way through the process.

2) Many of the plants found that they simply did not have excess capacity in key areas like distillation and fermentation. 
3) Feed handling for residue (corn stover) is unproven, and conceptual designs are believed to be costly. The capital associated with handling baled stover is estimated to be large, and the labor is anticipated to be high.

4) Having knowledgeable operations and laboratory staff was perceived to be one of the greatest benefits.

5) The enzymatic hydrolysis step is costly, and determining the actual costs of either purchasing enzyme or producing it on-site is difficult. The contractors found little information to use in estimating the cost of enzyme.

These results and recommendations can be tested on a co-location model, which is the next planned step for the joint USDA-ARS/NREL project. With a co-location model, scenarios and cost sensitivities can be investigated to help determine what scenarios might be promising. 


\section{References}

${ }^{1}$ Building a Bridge to the Corn Ethanol Industry, NREL Subcontract ZXE-9-18080-01. Work performed by Vogelbusch U.S.A. Inc., Houston, TX, January 10, 2000.

2 Building a Bridge to the Corn Ethanol Industry, NREL Subcontract ZXE-9-18080-05. Work performed by New York State Technology Enterprise Corporation, Rome, NT, December 31, 1999.

${ }^{3}$ Building a Bridge to the Corn Ethanol Industry, NREL Subcontract ZXE-9-18080-04. Work performed by Merrick \& Company, Aurora, CO, January, 2000.

4 "1998 corn production data," Corn Refiners Association Web page (www.corn.org/web/foodseed.htm).

${ }^{5}$ USDA Agricultural Prices - 1999 Summary, July 2000.

${ }^{6}$ Glassner, D; Hettenhaus, J.; and Schechinger, T. "Corn Stover Collection Project." BioEnergy '98-Expanding Bioenergy Partnerships: Proceedings, Volume 2, Madison, WI, pp. 11001110, 1998.

${ }^{7}$ Watson, S.; Ramstad, P.; Corn: Chemistry and Technology, 1987, American Association of Cereal Chemists, Inc., St. Paul, MN.

${ }^{8}$ Stover composition is an average of several samples collected from various regions and seasons, normalized with a soluble solids component that is considered similar to extractives. This is the composition used in the NREL design case for stover.

${ }^{9}$ DOE Energy Information Administration, (http://www.eia.doe.gov/fueloverview.html).

${ }^{10}$ Renewable Fuels Association "Home Grown Energy," Ethanol Industry Outlook - 1999 and Beyond.

${ }^{11}$ Raphael Katzen Associates, Grain Motor Fuel Alcohol Technical and Economic Assessment, June 1979.

${ }^{12}$ Raphael Katzen Associates, Ethanol from Corn, State of the Art Technology and Economics, unpublished presentation to the National Corn Growers Association Convention, June 1994.

${ }^{13}$ Andress, D., Ethanol Tax Incentives and Issues, subcontract report for Lockheed Martin Energy Systems Inc., and Office of Fuels Development. Work performed by David Andress and Associates, Inc., April 1998.

${ }^{14}$ Merrow, E.; Phillips, K.; and Myers, C.; Understanding Cost Growth and Performance Shortfalls in Pioneer Process Plants; report R-2569-DOE under contract DE-AC01-79PE70078 with DOE. Work performed by The Rand Corporation, September 1981.

${ }^{15}$ Delta-T Corporation, Williamsburg, VA, 23185, proprietary information, 1997.

${ }^{16}$ Wooley, R.; Ruth, M.; Sheehan, J.; Majdeski, H.; and Galvez, A. Lignocellulosic Biomass to Ethanol Process Design and Economics Utilizing Co-Current Dilute Acid Prehydrolysis and Enzymatic Hydrolysis Current and Futuristic Scenarios; Report No. NREL/TP-580-2615. National Renewable Energy Laboratory, Golden, CO, July 1999. Available at http://www.ott.doe.gov/biofuels/process engineering.htm.

${ }^{17}$ Distillers Grains Technology Council brochure.

${ }^{18}$ ASPEN Plus ${ }^{T M}$, Release 10.1, Aspen Technology, Inc., Cambridge, MA, October 1995. 
${ }^{19}$ Grethlein, H.; and Nelson, T.; Projected Process Economics for Ethanol Production from Corn, Michigan Biotechnology Institute, Lansing, MI, July 1992.

${ }^{20}$ Taylor, F.; Kurantz, M.J.; Goldberg, N.; McAloon, A.J.; and Craig, J.C. Jr. "Dry-Grind Process for Fuel Ethanol by Continuous Fermentation and Stripping," Biotechnology Progress, 16:541$547,2000$.

${ }^{21}$ Wooley, R.J. and Putsche, V. Development of an ASPEN PLUS Physical Property Database for Biofuels Components, NREL Report MP-425-20685, National Renewable Energy Laboratory, Golden, CO, April 1996.

${ }^{22}$ Bureau of Labor Statistics Data Web site (www.stats.bls.gov), "National Employment, Hours, and Earnings Catalog, Industry: Chemicals and Allied Products." Series ID: EEU322800006, Years: 1980-1996, annual average. Data extracted - December 29, 1997.

23 "U.S. Producer Price Indexes - Chemicals and Allied Products/Industrial Inorganic Chemicals Index," from the Chemical Economics Handbook, published by SRI Consulting, a division of SRI International, Menlo Park, CA, October 1997.

24 "Chemical Engineering Plant Cost Index," Chemical Engineering, May 1997.

${ }^{25}$ Remer, D.S.; Chai, L. "Estimate Costs of Scaled-up Process Plants," Chemical Engineering, April 1990.

26 "Process Plant Construction Estimating Standards," Process Equipment, Volume 4, Richardson Engineering Services, Inc., Mesa, AZ, 1993.

${ }^{27}$ ICARUS Process Evaluator, Version 4.0, ICARUS Corporation, Rockville, MD, June 30, 1997.

${ }^{28}$ Chemcost Capital Cost and Profitability Analysis Software, COADE/Chemstations Inc., 1985.

${ }^{29}$ DOE Energy Information Administration Average Cost of Wholesale Unleaded Gasoline in July 1997.

${ }^{30}$ Garrett, D.E., Chemical Engineering Economics, Van Nostrand Reinhold, New York, 1989.

${ }^{31}$ Peters, M.S. and Timmerhaus, K.D. Plant Design and Economics for Chemical Engineers, $4^{\text {th }}$ Edition, McGraw-Hill, Inc., New York, 1991.

${ }^{32}$ Douglas, F.R. et al, "Conducting Technical and Economic Evaluation in the Process and Utility Industries," AACE Recommended Practices and Standards, AACE, Inc., 1990.

${ }^{33}$ Feed Outlook, March 2000, USDA-ERS.

${ }^{34}$ Biomass to Ethanol Process Evaluation, NREL Final Subcontract Report. Work performed by Chem Systems, Tarrytown, NY: p. VI-10, December 1994. 
Appendix

Process Operating Costs and Summary 


\title{
Shelled Corn to Ethanol Process Analysis
}

ASPEN File: sde25a.bkp Excel File: 25econa.xls

All Values in $1999 \$$

\section{Annual Ethanol Production Cost \$0.88 Per Gallon}

\author{
Fuel Ethanol Production (MM Gal/Year) $25 \quad$ Ethanol at $68^{\circ} \mathrm{F}$ \\ Fuel Ethanol Yield (Gal/Bushel Corn) 2.85 \\ Feedstock Cost (\$/Bushel) \$1.94 15\% Moisture Content
}

\begin{tabular}{lr}
\multicolumn{2}{c}{ Variables that can be Changed } \\
\hline Cost Year for Analysis & 1999 \\
Life of Equipment & 10 \\
Days of Operation per Year & 330 \\
Volume \% Denaturant in Final Fuel Ethanol & $5 \%$ \\
Feedstock Cost (\$/Bushel) & $\$ 1.94$
\end{tabular}

\begin{tabular}{lr}
\multicolumn{2}{c}{ Operating Costs (\$/gal fuel ethanol) } \\
\hline Shelled Corn & $\$ 0.681$ \\
Other Raw Materials & $\$ 0.062$ \\
Denaturant & $\$ 0.026$ \\
Utilities & $\$ 0.159$ \\
Labor, Supplies, \& Overhead & $\$ 0.126$ \\
Depreciation of Capital & $\$ 0.112$ \\
DDG Credit & $-\$ 0.285$ \\
Total Product Cost per gallon & $\$ 0.881$
\end{tabular}

Total Capital Investment

$\$ 27,900,000$

\begin{tabular}{lr}
\multicolumn{2}{c}{ Operating Costs $(\$ / y r)$} \\
\hline Shelled Corn & $\$ 17,000,000$ \\
Other Raw Materials & $\$ 1,600,000$ \\
Denaturant & $\$ 600,000$ \\
Utilities & $\$ 4,000,000$ \\
Labor, Supplies, \& Overhead & $\$ 3,100,000$ \\
Depreciation of Capital & $\$ 2,800,000$ \\
DDG Credit & $-\$ 7,100,000$ \\
Total Annual Production Cost & $\$ 22,000,000$
\end{tabular}


Operating Costs

25MM Annual Gallons Fuel Ethanol from Starch

\begin{tabular}{|lr|}
\hline Cost Year for Analysis & 1999 \\
Total Installed Equipment Cost & $\$ 27,900,000$ \\
Life of Equipment & 10 \\
Ethanol Density (kg/L) & 0.7894 \\
Days per Year & 330 \\
Operating Hours per Year & 7,920
\end{tabular}

Variable Operating Costs

\begin{tabular}{|c|c|c|c|c|c|c|c|}
\hline Raw Material & Stream & $\begin{array}{r}\mathrm{kg} / \mathrm{hr} \text { or cal/sec } \\
\text { or } \mathrm{kW}\end{array}$ & $\begin{array}{r}\text { Ib/hr or } 10^{6} \\
\text { BTU/hr }\end{array}$ & $\begin{array}{r}(\$ / l b \text { or } \$ / \mathrm{kWh} \\
\left.\text { or } \$ / 10^{6} \mathrm{BTU}\right) \\
\end{array}$ & \$/hour (1999) & $\$ / y r(1999)$ & $\begin{array}{c}\text { \$/Gallon Fuel } \\
\text { Ethanol (1999) }\end{array}$ \\
\hline Corn Feedstock & 1GRAIN & 28,157 & 62,086 & 0.0346 & $\$ 2,150.82$ & $\$ 17,034,522$ & $\$ 0.681$ \\
\hline Caustic & CIP & 147 & 323 & 0.0550 & $\$ 17.79$ & $\$ 140,871$ & $\$ 0.006$ \\
\hline Alpha-Amylase & AAMYL & 20 & 45 & 1.2500 & $\$ 56.26$ & $\$ 445,576$ & $\$ 0.018$ \\
\hline Gluco-Amylase & GAMYL & 29 & 65 & 1.2500 & $\$ 81.26$ & $\$ 643,610$ & $\$ 0.026$ \\
\hline Denaturant (Gasoline) & GAS & 411 & 906 & 0.0898 & $\$ 81.32$ & $\$ 644,030$ & $\$ 0.026$ \\
\hline Sulfuric Acid & ACID & 58 & 128 & 0.0125 & $\$ 1.60$ & $\$ 12,707$ & $\$ 0.001$ \\
\hline Lime & LIME & 35 & 77 & 0.0350 & $\$ 2.68$ & $\$ 21,257$ & $\$ 0.001$ \\
\hline Makeup Water & MAKEUP & 8,910 & 19,647 & 0.0000 & $\$ 0.39$ & $\$ 3,112$ & $\$ 0.000$ \\
\hline Urea & UREA & 58 & 128 & 0.0500 & $\$ 6.42$ & $\$ 50,827$ & $\$ 0.002$ \\
\hline Yeast & YEAST & 6 & 12 & 2.5000 & $\$ 30.32$ & $\$ 240,125$ & $\$ 0.010$ \\
\hline Subtotal & & & & & $\$ 2,428.87$ & $\$ 19,236,636$ & $\$ 0.770$ \\
\hline \multicolumn{8}{|l|}{ Utilities } \\
\hline Steam - $150 \mathrm{PSI}$ & $\mathrm{kg} / \mathrm{hr}$ & 27,681 & 61,036 & 0.0045 & $\$ 274.66$ & $\$ 2,175,324$ & $\$ 0.087$ \\
\hline CT Water - 85 F & $\mathrm{kg} / \mathrm{hr}$ & $1,040,224$ & $2,293,693$ & 0.0000 & $\$ 29.82$ & $\$ 236,159$ & $\$ 0.009$ \\
\hline Cool Water $60 \mathrm{~F}$ & $\mathrm{~kg} / \mathrm{hr}$ & 270,390 & 596,210 & 0.0000 & $\$ 11.92$ & $\$ 94,440$ & $\$ 0.004$ \\
\hline Electricity & kW & 2,042 & & 0.0400 & $\$ 81.66$ & $\$ 646,782$ & $\$ 0.026$ \\
\hline Natural Gas & $\mathrm{cal} / \mathrm{sec}$ & $2,459,386$ & 35.1341 & 2.9500 & $\$ 103.65$ & $\$ 820,873$ & $\$ 0.033$ \\
\hline Subtotal & & & & & $\$ 501.71$ & $\$ 3,973,577$ & $\$ 0.159$ \\
\hline \multicolumn{8}{|l|}{ By-Product Credits } \\
\hline DDGS & DDGS & 9,205 & 20,297 & 0.0443 & $\$ 898.84$ & $\$ 7,118,806$ & $\$ 0.285$ \\
\hline Carbon Dioxide & $\mathrm{CO} 2$ & 8,621 & 19,008 & 0.0000 & $\$ 0.00$ & $\$ 0$ & $\$ 0.000$ \\
\hline Subtotal & & & & & & $\$ 7,118,806$ & $\$ 0.285$ \\
\hline Total Variable Operating Costs & & & & & $\$ 2,031.74$ & $\$ 16,091,407$ & $\$ 0.644$ \\
\hline
\end{tabular}

Labor, Supplies \& Overheads

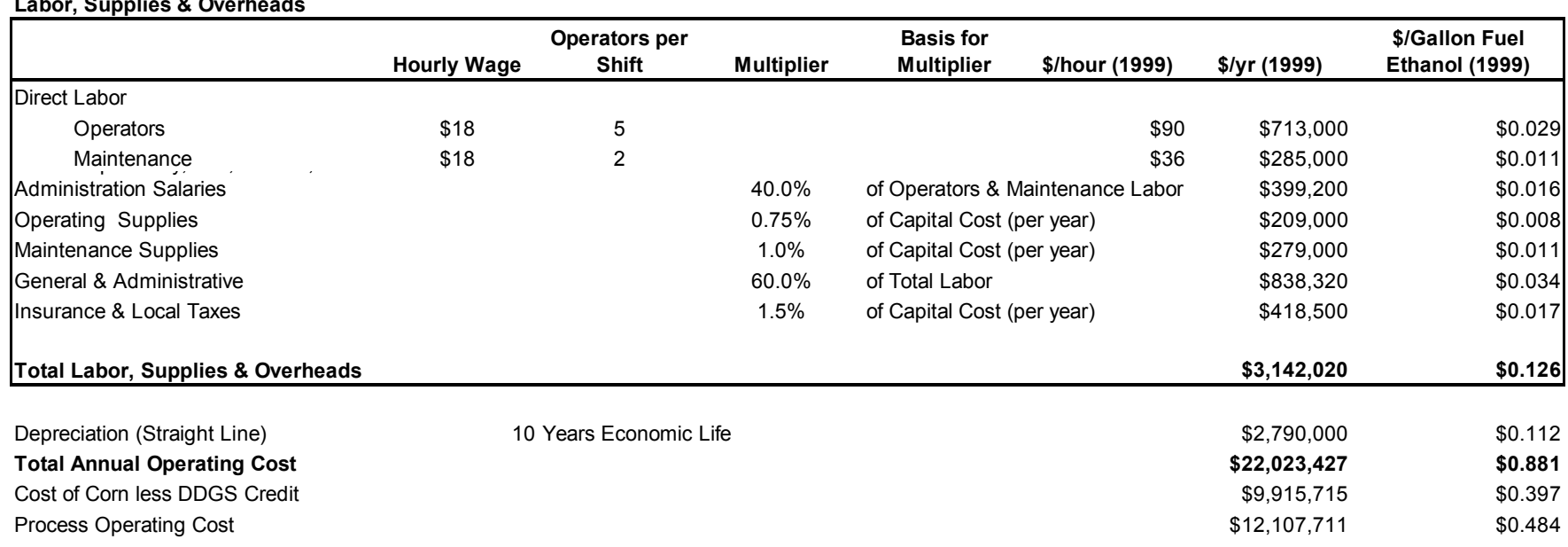




\section{Cellulose to Ethanol Process Analysis}

ASPEN File: 10004D.bkp Excel File: 10004DCSUSDA25M.xls

All Values in 1999\$

Enyzmatic Hydrolysis with Dilute Acid Prehydrolysis Annual Ethanol Production Cost \$1.50 Per Gallon

Fuel Ethanol Production (MM Gal/Year) 25

Fuel Ethanol Yield (Gal/Dry US Ton Corn Stover) 72

Feedstock Cost (\$/Dry US Ton) 35
Ethanol at $68^{\circ} \mathrm{F}$

$15 \%$ Moisture Content
Variables that can be Changed

\begin{tabular}{lc}
\hline Cost Year for Analysis & 1999 \\
Life of Equipment & 10 \\
Days of Operation per Year & 330 \\
$\%$ Denaturant in Final Fuel Ethanol & $5 \%$ \\
Feedstock Cost (\$/Dry US Ton) & $\$ 35$
\end{tabular}

Installed Capital Costs

\begin{tabular}{l}
\hline Feed Handling \\
Pretreatment/Conditioning \\
Simultaneous Saccharification/Co-fermentation \\
Cellulase Production \\
Distillation \\
Solids/Syrup Separation \\
Wastewater Treatment \\
Storage \\
Boiler/Turbogenerator \\
Utilities \\
Total Capital Investment
\end{tabular}

$\$ 5,400,000$
$\$ 29,800,000$
$\$ 14,400,000$
$\$ 18,100,000$
$\$ 5,100,000$
$\$ 9,200,000$
$\$ 9,000,000$
$\$ 2,100,000$
$\$ 37,500,000$
$\$ 5,500,000$
$\$ 136,100,000$

$\$ 5,400,000$

$\$ 29,800,000$

$\$ 14,400,000$

$\$ 18,100,000$

$\$ 5,100,000$

$\$ 9,200,000$

$\$ 9,000,000$

$\$ 2,100,000$

$\$ 5,500,000$

$\$ 136,100,000$

\begin{tabular}{lc}
\multicolumn{2}{c}{ Operating Costs (\$/gal fuel ethanol) } \\
\hline Corn Stover & $\$ 0.485$ \\
Corn Steep Liquor & $\$ 0.049$ \\
Other Raw Materials & $\$ 0.121$ \\
Denaturant & $\$ 0.025$ \\
Waste Disposal & $\$ 0.027$ \\
Labor, Supplies, and Overhead & $\$ 0.356$ \\
Depreciation of Capital & $\$ 0.544$ \\
Electricity Credit & $-\$ 0.111$ \\
Total Product Cost per gallon & $\$ 1.496$
\end{tabular}

\begin{tabular}{lr}
\multicolumn{2}{c}{ Operating Costs $(\$ / \mathrm{yr})$} \\
\hline Corn Stover & $\$ 12,100,000$ \\
Corn Steep Liquor & $\$ 1,200,000$ \\
Other Raw Materials & $\$ 3,000,000$ \\
Denaturant & $\$ 600,000$ \\
Waste Disposal & $\$ 700,000$ \\
Labor, Supplies, and Overhead & $\$ 8,900,000$ \\
Depreciation of Capital & $\$ 13,600,000$ \\
Electricity Credit & $-\$ 2,800,000$ \\
Total Annual Production Cost & $\$ 37,300,000$ \\
\cline { 2 - 2 } Excess Electricity (KWH/gal) & \\
\end{tabular}


Operating Costs

25MM Annual Gallons Fuel Ethanol from Corn Stover

\begin{tabular}{|c|c|c|c|}
\hline Cost Year for Analysis & 1999 & Pure Ethanol (kg/hr) & 8,959 \\
\hline Total Installed Equipment Cost & $\$ 136,000,000$ & Pure Ethanol Production Rate (gal/yr) & $23,744,657$ \\
\hline Life of Equipment & 10 & Denaturant Density $(\mathrm{kg} / \mathrm{L})$ & 0.6875 \\
\hline Ethanol Density (kg/L) & 0.7894 & Denaturant in Final Product (\% volume/volume) & $5 \%$ \\
\hline Days per Year & 330 & Annual Fuel Ethanol Production (gal) & $24,994,375$ \\
\hline Operating Hours per Year & 7,920 & Annual Fuel Ethanol Production (MM gal) & 25 \\
\hline
\end{tabular}

Variable Operating Costs

\begin{tabular}{|c|c|c|c|c|c|c|c|}
\hline Raw Material & Stream & $\mathrm{Kg} / \mathrm{hr}$ & Lb/hr & 1999 Cost (\$/lb) & \$/hour (1999) & $\$ / y r$ (1999) & $\begin{array}{l}\text { \$/Gallon Fuel } \\
\text { Ethanol (1999) }\end{array}$ \\
\hline Corn Stover Feedstock & STRM0101 & 46,667 & 102,901 & 0.014875 & $\$ 1,530.65$ & $\$ 12,122,751$ & $\$ 0.485$ \\
\hline Sulfuric Acid & STRM0710 & 1,629 & 3,593 & 0.0125 & $\$ 44.91$ & $\$ 355,659$ & $\$ 0.014$ \\
\hline Lime & STRM0745 & 428 & 944 & 0.0350 & $\$ 33.05$ & $\$ 261,732$ & $\$ 0.010$ \\
\hline Ammonia & STRM0717 & 689 & 1,519 & 0.0875 & $\$ 132.93$ & $\$ 1,052,831$ & $\$ 0.042$ \\
\hline Corn Steep Liquor & STRM0735 & 918 & 2,025 & 0.0761 & $\$ 154.07$ & $\$ 1,220,216$ & $\$ 0.049$ \\
\hline Nutrients & STRM0415 & 66 & 145 & 0.1400 & $\$ 20.35$ & $\$ 161,140$ & $\$ 0.006$ \\
\hline Ammonium Sulfate & STRM0420 & 158 & 349 & 0.0228 & $\$ 7.97$ & $\$ 63,114$ & $\$ 0.003$ \\
\hline Antifoam & STRM0417 & 106 & 234 & 0.2558 & $\$ 59.81$ & $\$ 473,658$ & $\$ 0.019$ \\
\hline Diesel & STRM0723 & 214 & 472 & 0.0630 & $\$ 29.71$ & $\$ 235,309$ & $\$ 0.009$ \\
\hline Makeup Water & STRM0903 & 100,528 & 221,665 & 0.0001 & $\$ 30.51$ & $\$ 241,658$ & $\$ 0.010$ \\
\hline BFW Chemicals & STRM0921 & 0 & 1 & 1.5801 & $\$ 0.95$ & $\$ 7,496$ & $\$ 0.000$ \\
\hline CW Chemicals & STRM0922 & 4 & 9 & 1.0000 & $\$ 8.67$ & $\$ 68,694$ & $\$ 0.003$ \\
\hline WWT Nutrients & STRM0630 & 55 & 122 & 0.1100 & $\$ 13.43$ & $\$ 106,405$ & $\$ 0.004$ \\
\hline WWT Chemicals & STRM0631 & 0.18 & 0.40 & 2.5000 & $\$ 0.99$ & $\$ 7,835$ & $\$ 0.000$ \\
\hline Denaturant (Gasoline) & & 390.12 & 860.21 & 0.0924 & $\$ 79.51$ & $\$ 629,739$ & $\$ 0.025$ \\
\hline Subtotal & & & & & $\$ 2,147.50$ & $\$ 17,008,236$ & $\$ 0.680$ \\
\hline \multicolumn{8}{|l|}{ Waste Streams } \\
\hline Solids Disposal & STRM804C & 2,514 & 5,543 & 0.01 & $\$ 54.55$ & $\$ 432,025$ & $\$ 0.017$ \\
\hline Solids Disposal & STRM0229 & 1,385 & 3,055 & 0.01 & $\$ 30.06$ & $\$ 238,102$ & $\$ 0.010$ \\
\hline Subtotal & & & & & $\$ 84.61$ & $\$ 670,126$ & $\$ 0.027$ \\
\hline By-Product Credits & & KW & & $\$ / K W h$ & & & \\
\hline Electricity Generated & WKBLRNET & $(17,976)$ na & & 0.040 & $-\$ 719.04$ & $-\$ 5,694,808$ & $-\$ 0.228$ \\
\hline Electricity Consumption & & 9,229 na & & 0.040 & $\$ 369.15$ & $\$ 2,923,671$ & $\$ 0.117$ \\
\hline Electricity Required/(Excess) & & $(8,747)$ & & & $-\$ 349.89$ & $-\$ 2,771,137$ & $-\$ 0.111$ \\
\hline Total Variable Operating Costs & & & & & $\$ 1,882.23$ & $\$ 14,907,225$ & $\$ 0.596$ \\
\hline
\end{tabular}

Labor, Supplies \& Overheads

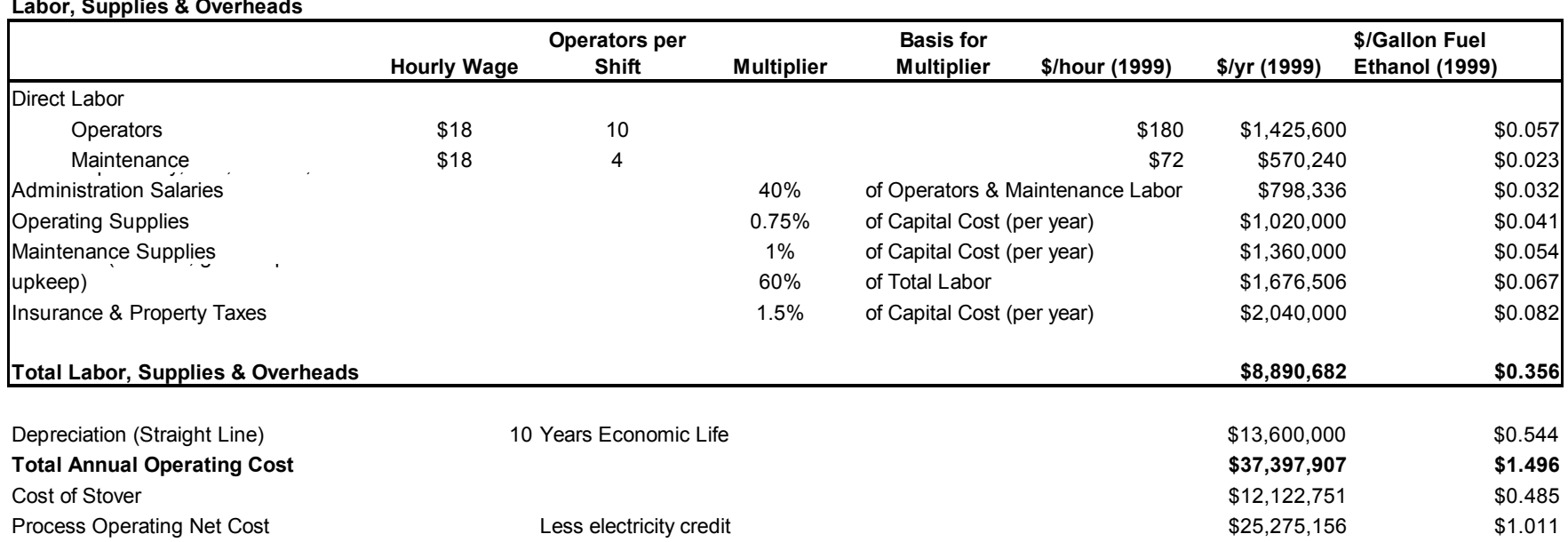




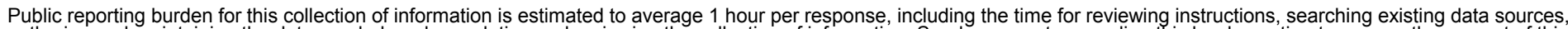

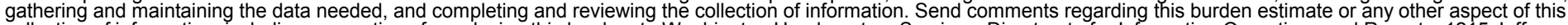

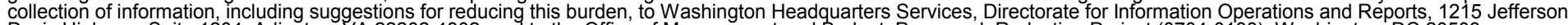
Davis Highway, Suite 1204, Arlington, VA 22202-4302, and to the Office of Management and Budget, Paperwork Reduction Project (0704-0188), Washington, DC 20503.

\begin{tabular}{|l|l|l|l|}
\hline 1. AGENCY USE ONLY (Leave blank) & $\begin{array}{l}\text { 2. REPORT DATE } \\
\text { October } 2000\end{array}$ & $\begin{array}{l}\text { 3. REPORT TYPE AND DATES COVERED } \\
\text { Technical Report }\end{array}$ \\
\hline 4. TITLE AND SUBTITLE &
\end{tabular}

4. TITLE AND SUBTITLE
Determining the Cost of Producing Ethanol from Corn Starch and Lignocellulosic Feedstocks

5. FUNDING NUMBERS

T: BFP1.7110

6. $\mathrm{AUTHOR}(\mathrm{S})$

Andrew McAloon, Frank Taylor, Winnie Yee, Kelley Ibsen, Robert Wooley

7. PERFORMING ORGANIZATION NAME(S) AND ADDRESS(ES)

8. PERFORMING ORGANIZATION REPORT NUMBER

9. SPONSORING/MONITORING AGENCY NAME(S) AND ADDRESS(ES)

U.S. Department of Agriculture

10. SPONSORING/MONITORING AGENCY REPORT NUMBER

Eastern Regional Research Center

Agricultural Research Service

NREL/TP-580-28893

Wyndmoor, PA 19038

and

National Renewable Energy Laboratory

1617 Cole Blvd.

Golden, CO 80401-3393

11. SUPPLEMENTARY NOTES

A Joint Study Sponsored by: U.S. Department of Agriculture and U.S. Department of Energy

12a. DISTRIBUTION/AVAILABILITY STATEMENT

National Technical Information Service

12b. DISTRIBUTION CODE

U.S. Department of Commerce

5285 Port Royal Road

Springfield, VA 22161

13. ABSTRACT (Maximum 200 words) The mature corn-to-ethanol industry has many similarities to the emerging lignocellulose-to-ethanol industry. It is certainly possible that some of the early practitioners of this new technology will be the current corn ethanol producers. In order to begin to explore synergies between the two industries, a joint project between two agencies responsible for aiding these technologies in the Federal government was established. This joint project of the USDA-ARS and DOE/NREL looked at the two processes on a similar process design and engineering basis, and will eventually explore ways to combine them. This report describes the comparison of the processes, each producing 25 million annual gallons of fuel ethanol. This paper attempts to compare the two processes as mature technologies, which requires assuming that the technology improvements needed to make the lignocellulosic process commercializable are achieved, and enough plants have been built to make the design well-understood. Assumptions about yield and design improvements possible from continued research were made for the emerging lignocellulose process. In order to compare the lignocellulose-to-ethanol process costs with the commercial corn-to-ethanol costs, it was assumed that the lignocellulose plant was an $\mathrm{N}^{\text {th }}$ generation plant, built after the industry had been sufficiently established to eliminate first-of-a-kind costs. This places the lignocellulose plant costs on a similar level with the current, established corn ethanol industry, whose costs are well known. The resulting costs of producing 25 million annual gallons of fuel ethanol from each process were determined. The figure below shows the production cost breakdown for each process. The largest cost contributor in the corn starch process is the feedstock; for the lignocellulosic process it is the capital cost, which is represented by depreciation cost on an annual basis.

\begin{tabular}{|c|c|c|c|}
\hline \multirow{2}{*}{\multicolumn{3}{|c|}{$\begin{array}{l}\text { 14. SUBJECT TERMS } \\
\text { lignocellulose; corn ethanol; USDA }\end{array}$}} & 15. NUMBER OF PAGES \\
\hline & & & 16. PRICE CODE \\
\hline $\begin{array}{l}\text { 17. SECURITY CLASSIFICATION } \\
\text { OF REPORT } \\
\text { Unclassified }\end{array}$ & $\begin{array}{l}\text { 18. SECURITY CLASSIFICATION } \\
\text { OF THIS PAGE } \\
\text { Unclassified }\end{array}$ & $\begin{array}{l}\text { 19. SECURITY CLASSIFICATION } \\
\text { OF ABSTRACT } \\
\text { Unclassified }\end{array}$ & $\begin{array}{l}\text { 20. LIMITATION OF ABSTRACT } \\
\text { UL }\end{array}$ \\
\hline
\end{tabular}

